\title{
ORIGINAL ARTICLE \\ Extensive mitochondrial introgression in North American Great Black-backed Gulls (Larus marinus) from the American Herring Gull (Larus smithsonianus) with little nuclear DNA impact
}

\author{
J-M Pons ${ }^{1,2}$, S Sonsthagen ${ }^{3}$, C Dove $^{3}$ and P-A Crochet ${ }^{4}$ \\ Recent genetic studies have shown that introgression rates among loci may greatly vary according to their location in the \\ genome. In particular, several cases of mito-nuclear discordances have been reported for a wide range of organisms. In the \\ present study, we examine the causes of discordance between mitochondrial (mtDNA) and nuclear DNA introgression detected \\ in North American populations of the Great Black-backed Gull (Larus marinus), a Holarctic species, from the Nearctic North \\ American Herring Gull (Larus smithsonianus). Our results show that extensive unidirectional mtDNA introgression from Larus \\ smithsonianus into Larus marinus in North America cannot be explained by ancestral polymorphism but most likely results from \\ ancient hybridization events occurring when Larus marinus invaded the North America. Conversely, our nuclear DNA results \\ based on 12 microsatellites detected very little introgression from Larus smithsonianus into North American Larus marinus. We \\ discuss these results in the framework of demographic and selective mechanisms that have been postulated to explain mito- \\ nuclear discrepancies. We were unable to demonstrate selection as the main cause of mito-nuclear introgression discordance \\ but cannot dismiss the possible role of selection in the observed pattern. Among demographic explanations, only drift in small \\ populations and bias in mate choice in an invasive context may explain our results. As it is often difficult to demonstrate that \\ selection may be the main factor driving the introgression of mitochondrial DNA in natural populations, we advocate that \\ evaluating alternative demographic neutral hypotheses may help to indirectly support or reject hypotheses invoking selective \\ processes.
}

Heredity (2014) 112, 226-239; doi:10.1038/hdy.2013.98; published online 9 October 2013

Keywords: hybridization; mitochondrial DNA; microsatellites; speciation; Larus; North America

\section{INTRODUCTION}

Recent genetic studies have shown that at least $25 \%$ of plant species and $10 \%$ of animal species are involved in natural hybridization and potential introgression (Mallet, 2005). In birds, around 10\% of species are known to hybridize (Grant and Grant, 1992), with some families having a strong propensity for hybridization. In Paradisaeidae (birds of paradise), for example, $43 \%$ of species hybridize in nature (Mallet, 2005). How these species can maintain their behavioral, phenotypic and ecological differences in the face of prevailing interspecific gene flow is an exciting question for speciation studies (for example, Pinho and Hey, 2010; Rice et al., 2011). Relevant information regarding the consequences of interspecific gene flow on a species' genome can be gained from examining variations in the pattern of introgression among loci (for example, Barton and Hewitt, 1985; Barton and Gale, 1993; Gay et al., 2007; Luttikhuizen et al., 2012). Indeed, one general pattern that emerges from recent studies is that introgression rates among loci may greatly vary according to their location in the genome. In particular, several studies have reported cases of mito- nuclear discordances with introgression of mitochondrial DNA and low or even apparent absence of nuclear introgression (fish: Wilson and Bernatchez, 1998, birds: Bellemain et al., 2008; Irwin et al., 2009, mammals: Roca et al., 2005; Good et al., 2008; Melo-Ferreira et al., 2009, amphibians: Zieliński et al., 2013). The reverse situation, high nuclear introgression with low mitochondrial introgression or lack of mitochondrial introgression has also been observed in butterflies, a primate species and birds species (Steeves et al., 2010, see also Petit and Excoffier, 2009 for a review).

Several factors have been postulated to explain these mito-nuclear discrepancies (reviewed by Toews and Brelsford, 2012). They can be divided between selection on mitochondrial DNA variants and demographic processes, such as sex-biased dispersal and sex-specific premating or postmating barriers. One key factor enabling researchers to disentangle demographic and selective factors shaping mitonuclear discrepancies is the amount of nuclear introgression relative to mitochondrial introgression. Specifically, as autosomal loci are transmitted by both sexes, it is difficult to imagine how demographic

1UMR7205 Origine, Structure et Evolution de la Biodiversité, Département Systématique et Evolution, Muséum National d'Histoire Naturelle, Paris, France; ${ }^{2}$ Service de Systématique Moléculaire, UMS 2700, Muséum National d'Histoire Naturelle, Paris, France; ${ }^{3}$ Department of Vertebrate Zoology, Division of Birds, National Museum of Natural History, Smithsonian Institution, Washington, DC, USA and ${ }^{4}$ CNRS_UMR5175 CEFE, Centre d'Ecologie Fonctionnelle et Evolutive, Montpellier Cedex 5, France Correspondence: Dr J-M Pons, Origine, Structure et Evolution de la biodiversité, UMR 7205, Département Systématique et Evolution, Muséum National d'Histoire Naturelle, 55 rue de Buffon, CP 51, Paris 75005, France.

E-mail: pons@mnhn.fr

Received 12 April 2013; revised 31 July 2013; accepted 15 August 2013; published online 9 October 2013 
processes such as sex-biased gene flow could result in substantial mitochondrial introgression without detectable traces of nuclear introgression (see Renoult et al., 2009).

Among birds, Laridae are famous for their propensity to hybridize in nature (see Olsen and Larsson, 2004), especially the group known as 'the large white-headed gulls' (Sonsthagen et al., 2012) or 'the Herring Gull complex' (Sternkopf et al., 2010). These species include some of the best documented avian hybrid zones (Hoffman et al., 1978; Bell, 1997; Good et al., 2000; Good, 2002; Gay et al., 2007, 2009; Neubauer et al., 2009), and are remarkable for their low level of interspecific genetic differentiation compared with most biological species of birds, resulting from recent speciation events and on-going interspecific gene flow (de Knijff et al., 2001; Crochet et al., 2003; Vigfúsdóttir et al., 2008; Sternkopf et al., 2010; Sonsthagen et al., 2012). Extensive introgression of mtDNA has been documented in several species (Crochet et al., 2003; Gay et al., 2007; Sternkopf et al., 2010; Sonsthagen et al., 2012). They thus constitute a promising model to address the causes of discordance between mtDNA and nuclear DNA introgression and the consequences of interspecific hybridization on the outcome of speciation processes.

Extensive mtDNA introgression has been documented between Great Black-backed Gull (Larus marinus) and American Herring Gull (Larus smithsonianus) in North America (Crochet et al., 2003; Sternkopf et al., 2010). Great Black-backed Gull (MARINUs hereafter) is a Holarctic species distributed in Western Europe, Greenland and eastern North America (Olsen and Larsson, 2004) and is a member of a clade comprising several western European gull species closely related to the Herring Gull (Crochet et al., 2003; Liebers et al., 2004; Sternkopf et al., 2010). American Herring Gull (sMithsonianus hereafter) is widely distributed in North America; it groups with the 'Arctic species clade', which is the sister group to the European species clade (Crochet et al., 2002; Liebers et al., 2004; Sternkopf et al., 2010) and is thus not the closest relative of MARINUS. Genetic data suggest that MARINUS originated in Europe and colonized eastern North American coast where it came into secondary contact with SMITHSONIANUS (Crochet et al., 2003; Sternkopf et al., 2010). Currently, a large proportion of North American MARINUS carries SMITHSONIANUS mtDNA haplotypes (the SMI haplotype hereafter) (Sternkopf et al., 2010). As only American MARINUS share SMI mtDNA haplotypes with SMITHSONIANUS, whereas SMI haplotypes are completely absent from Europe (even in other species of the Herring Gull complex), MARINUs populations in North America likely received SMI haplotypes by introgression rather than through the persistence of ancestral polymorphism in both species.

In this study, we aim to enhance our understanding of the evolutionary processes promoting mtDNA introgression by directly testing for the genetic contribution from SMITHSONIANUS to the nuclear gene pool of North American MARINUs. As discussed above, an agreement between the amount of nuclear and mtDNA introgression would indicate that neutral processes drive mtDNA introgression, while a large discrepancy in introgression rate would call for alternative explanations. We first assayed cytochrome $b$ (cyt $b$ ) and control region fragments to measure mitochondrial introgression in samples of North American populations of SMITHSONIANUs and MARINUS. We then compare results of multivariate analysis (Factorial Correspondence Analysis (FCA)) and assignment methods (NewHybrids, based on Anderson and Thompson, 2002) between European and North American individuals of MARINUs using 12 microsatellite loci. If SMITHSONIANUS contributed to the nuclear gene pool of North American MARINUS, we would expect that (1) North American MARINUS are situated between European MARINUS and
SMITHSONIANUS in bivariate plots of factorial scores and (2) assignment scores also differ between European and North American MARINUS, with North American MARINUs individuals having lower probabilities of assignment to MARINUS and higher to SMITHSONIANUS than European individuals. Field data suggest that contemporary hybridization is very rare in North America (Jehl, 1960; Andrle, 1972), suggesting introgression through historical hybridization events when MARINUS colonized North America probably during late Pleistocene or Holocene rather than contemporary gene flow. We first evaluated this hypothesis with NewHybrids, testing for the absence of individuals originating from recent hybridization events (F1 or backcrosses) between SMITHSONIANUS and MARINUs in our samples from North America. We also compared FCA scores and assignment probabilities of North American MARINUS specimens carrying SMI and MAR (the original MARINUS haplotype, see Crochet et al., 2003) haplotypes: if they do not differ, then recent hybridization events contribute very little (at best) to current lineage sharing.

\section{MATERIALS AND METHODS}

We obtained tissue samples (blood, muscle or feathers, $n=116$ ) from 49 North American L. marinus individuals, 15 European L. marinus individuals and 52 L. smithsonianus individuals were collected or obtained through museum tissue loans. Thirty-two tissue samples were collected from unrelated chicks at the Iles Sainte-Marie, Quebec, Canada. Other tissue samples were obtained mainly from adults that were collected in diverse localities spread over eastern and southern USA and do not necessarily correspond with birds sampled close to breeding locations. Information on sampling locations is given in the Table 1 and additional information on specimens and localities assayed in the study is reported in Appendix 1. In addition, 19 HVR-I sequences available in GenBank (see Appendix 1) were included in the analyses.

Table 1 Geographical distribution and frequency of specimens assayed in this study

\begin{tabular}{|c|c|c|c|}
\hline \multirow[t]{2}{*}{ Localities } & \multicolumn{2}{|c|}{ L. marinus } & \multirow{2}{*}{$\begin{array}{l}\text { L. smithsonianus } \\
\text { North American }\end{array}$} \\
\hline & European & North American & \\
\hline \multicolumn{4}{|l|}{ Europe } \\
\hline Denmark & 1 & & \\
\hline Faroe islands & $9^{a}$ & & \\
\hline Finland & 6 & & \\
\hline France & 4 & & \\
\hline Sweden & 5 & & \\
\hline \multicolumn{4}{|l|}{ Canada } \\
\hline Quebec & & 12 & 20 \\
\hline Ontario & & & $11^{\mathrm{a}}$ \\
\hline \multicolumn{4}{|l|}{ United States } \\
\hline Alaska & & & 5 \\
\hline California & & & 3 \\
\hline Louisiana & & 2 & 7 \\
\hline Maine & & 4 & \\
\hline Massachusetts & & 2 & \\
\hline Maryland & & 6 & 7 \\
\hline Missouri & & 2 & \\
\hline New York & & 16 & 8 \\
\hline New Jersey & & & 2 \\
\hline North Carolina & & 2 & \\
\hline Virginia & & 3 & \\
\hline
\end{tabular}

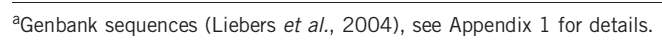




\section{Mitochondrial DNA (mtDNA) sequencing}

We amplified a 391 base pair (bp) fragment of the HVR-I part of the control region using primers L15610 5'-TTACCCCCCCACAWCATCATGTGG-3' (designed for this study) and H519 (Liebers et al., 2001) or L15522 and H1816 (Sonsthagen et al., 2012). A 389-bp cyt $b$ fragment was amplified using primers L14967, H15503 or H15938 (Pons et al., 2004). The amplification protocol was: $4 \mathrm{~min}$ at $94^{\circ} \mathrm{C}$, followed by 36 cycles of $94^{\circ} \mathrm{C}$ for $40 \mathrm{~s}, 52-60^{\circ} \mathrm{C}$ for $45 \mathrm{~s}, 72{ }^{\circ} \mathrm{C}$ for $40-50 \mathrm{~s}$, with a final extension at $72{ }^{\circ} \mathrm{C}$ for $10 \mathrm{~min}$. Cyclesequencing reactions were performed using the CEQ Dye Terminator Cycle Sequencing kit (Beckman Coulter, Inc., Fullerton, CA, USA) or the Big Dye (Applied Biosystems Inc., Foster City, CA, USA) terminator chemistries kit using L15610 and H519 or H419 and H519 (Liebers et al., 2001). PCR amplifications were sequenced on automated sequencers (CEQ2000 DNA Analysis System (Beckman Coulter Inc., Fullerton, CA, USA) or ABI3100 (Life Technologies, Carlsbad, CA, USA)). Sequences were aligned using Bioedit software (Hall, 1999). Alignment of the HVR-I sequences required the insertion of single-nucleotide gaps at one site, which were deleted before analyses. Cyt $b$ sequences did not contain any unexpected stop-codons.

\section{Microsatellites genotyping}

Following preliminary testing on large white-headed gull species (see Sonsthagen et al., 2012), 12 polymorphic loci were scored on all tissue samples: Hg16, Hg18, Hg25 (Crochet et al., 2003), K16 (Tirard et al., 2002), LarZAP12, LarZAP19, LarSNX24, LarZAP26 (Gregory and Quinn 2006), Rbg13, Rbg18, Rbg27, and Rbg29 (Given et al., 2002). PCR amplifications and subsequent genotyping followed Sonsthagen et al. (2012). Ten percent of the samples were amplified and genotyped in duplicate for quality control, and no inconsistencies in genotype scores were observed between replicates.

\section{Data analyses}

Mitochondrial DNA. Standard diversity indices (number of substitutions, haplotype diversity $(h)$, nucleotide diversity $(\pi)$ ) were calculated using Arlequin 3.1 (Excoffier et al., 2005). Tajima's $D$ statistic (Tajima, 1989) and Fu's $F_{S}$ statistic $(\mathrm{Fu}, 1997)$ were computed in Arlequin 3.1 to test for selective neutrality. Analyses of molecular variance were performed using the Kimura two parameter model (K2P; Kimura, 1980); the closest nucleotide substitution model available in Arlequin 3.1 to the K2P with an invariant site parameter $(\mathrm{K} 2 \mathrm{P}+\mathrm{I})$ model, which was selected as the best model for our HVR-I sequence data in Modeltest 3.4 (Posada and Crandall, 2001). To visualize the relationships among haplotypes and the sharing of haplotypes among species and geographical populations, median-joining networks based on HVR-I and cyt $b$ haplotypes were constructed using Network 4.2 (Bandelt et al., 1999).

Microsatellites. Measures of genetic diversity, population differentiation and departure from Hardy-Weinberg equilibrium were calculated in Genetix version 4.05 (Belkhir et al., 1996-2004). As several loci exhibited significant $F_{\mathrm{IS}}$, which can be due among other causes to null alleles, we examined our data with the software Microchecker (van Oosterhout et al., 2004).

We used the software NewHybrids version 1.1 beta 3 (implementing a method described in Anderson and Thompson, 2002) to obtain assignment probabilities of every individual to each of the following categories: pure MARINUS, pure SMITHSONIANUS, F1 hybrids, and backcross to MARINUS and to SMITHSONIANUS.

We retained results based on uniform prior for the mixing proportions and the allelic frequencies (see NewHybrids documentation) as they gave more consistent results (smaller number of individuals misclassified based on a priori identification, see Discussion). We tried to use the $z$ option, which allows specifying individuals of pure ancestry from each population, but results were generally less consistent. This is certainly because we had very few SMITHSONIANUS specimens sampled outside the zone of sympatry with MARINUS, and most of them were from Alaska. Substantial introgression from other large gull species into SMITHSONIANUS in Alaska has been well documented (Williamson and Peyton, 1963), and our Alaskan specimens had low probabilities of assignment to SMITHSONIANUS in all runs (with or without the $z$ option), indicating that they had multilocus genotypes not representative of other North American smithsonianus. Labeling them as 'pure' smithsonianus therefore reduced the reliability of the results. The number of sweeps for burn in was 500000 , and the results were based on 1000000 sweeps.

As genetic differentiation between the two parental populations (SMITHSONIANUS and European MARINUS) is rather low, we tested for the reliability of NewHybrids with our populations by using Hybridlab (Nielsen et al., 2001) to simulate random multilocus genotypes, based on observed allele frequencies. We generated virtual genotypes of pure European MARINUS, pure SMITHSONIANUS, F1 hybrids, backcross to SMITHSONIANUS and backcross to MARINUs (100 genotypes for each class) and analyzed them with NewHybrids, using the same options as for the real specimens.

For several individuals, genotypes were missing at one or more loci. As missing data could affect the reliability of the results, we first attempted to reduce the number of loci, hence reducing the number of missing data for some specimens. Two loci (Lar19 and Rbg18) did not exhibit any significant differentiation $\left(F_{\mathrm{ST}}\right.$ values, respectively, $0.029, P=0.11$ and 0$)$ between European MARINUS and SMITHSONIANUS and were excluded from subsequent analyses. We then performed separate NewHybrids analyses for individuals with at most four missing loci, for individuals with at most two missing loci and for individuals with no missing data and tested for differences in mean assignment scores between European and North American MARINUs for the three NewHybrids analyses.

We also used FCA of individual multilocus genotypes (FCA, in its modified version for diploid organisms: She et al., 1987, Guinand, 1996) as implemented in Genetix version 4.05 to test whether North American MARINUs gene pool was influenced by contributions from sMitHSONIANUs. For analysis of assignment scores, we used the $\operatorname{logit}(=\log (\operatorname{probability} /(1-$ probability $)))$ of the assignment probabilities, as assignment probabilities were not normally distributed. Number of missing loci was included in all models as a covariate, as it may affect assignment probabilities. FCA scores were analyzed directly using the same model (no logit transformation) as they were suitably distributed.

\section{RESULTS}

\section{Mitochondrial DNA}

All genetic diversity estimates highlighted that the European MARINUs population was more variable than their non-introgressed and introgressed North American counterparts. Nucleotide diversity and the mean number of pairwise differences were twofold higher in Europe (Table 2). Tajima's test of selective neutrality and Fu's test did not reject the neutral model neither for European MARINUs nor for introgressed and non-introgressed North American MARINUS. Mismatch distribution analyses supported the sudden expansion model (raggedness test, $P>0.50$ for all populations).

Pairwise $\Phi_{\mathrm{ST}}$ values indicated that the introgressed MARINUs population was highly differentiated from both the non-introgressed North American and European Marinus $\left(\Phi_{\mathrm{ST}}>0.7\right.$, Table 3$)$. Conversely, introgressed MARINUs was weakly differentiated from SMITHSONIANUS with only $7 \%$ of the variance explained by differences between populations. Expectedly, European and non-introgressed North American MARINUS populations exhibited little differentiation (Table 3).

The HVR-I median-joining network clearly showed that MARINUs haplotypes were clustered in two clades separated by four nucleotide substitutions (Figure 1a). One clade comprised all European haplotypes as well as MARINUs haplotypes observed in America. The two haplotypes in highest frequency were represented by gulls residing on both sides of the Atlantic Ocean while most of the other haplotypes are only observed in Europe. The second clade comprised all SMITHSONIANUS haplotypes with the two most frequent haplotypes also represented by North American MARINUs individuals. This overall structure of two clades is also observed among cyt $b$ haplotypes (Figure 1b). None of the European individuals clustered with the SMITHSONIANUS clade except one European MARINUs from Sweden. This bird possesses a haplotype also found in the sympatric species 
Table 2 Molecular diversity and tests of neutral evolution of the control region HVR-I of introgressed (I) and non-introgressed (NI) North American Larus marinus individuals and European L. marinus individuals, including number of haplotypes $(H)$, number of substitutions (NS), haplotype diversity $(h)$, nucleotide diversity $(\pi),(d)$ mean number of pairwise differences, Tajima's $D$ and Fu's $F_{\mathrm{S}}$

\begin{tabular}{|c|c|c|c|c|c|c|c|c|c|c|}
\hline & \multirow[t]{2}{*}{$n$} & \multirow[t]{2}{*}{ H } & \multirow[t]{2}{*}{ NS } & \multirow[t]{2}{*}{ h (s.d.) } & \multirow[t]{2}{*}{$\pi(s . d)}$. & \multirow[t]{2}{*}{$\mathrm{d}$ (s.d.) } & \multicolumn{2}{|c|}{ Tajima's D } & \multicolumn{2}{|c|}{$F u ' s F_{S}$} \\
\hline & & & & & & & D & $\mathrm{P}$ & $\mathrm{F}$ & $P$ \\
\hline \multicolumn{11}{|c|}{ Europe } \\
\hline (NI) & 24 & 11 & 17 & $0.877(0.043)$ & $0.0082(0.0049)$ & $3.20(1.72)$ & -1.43 & 0.06 & -2.75 & 0.08 \\
\hline \multicolumn{11}{|c|}{ North America } \\
\hline$(\mathrm{NI})$ & 21 & 6 & 6 & $0.738(0.081)$ & $0.0038(0.0027)$ & $1.48(0.93)$ & -1.06 & 0.18 & -1.01 & 0.25 \\
\hline (I) & 28 & 8 & 9 & $0.733(0.069)$ & $0.0048(0.0031)$ & $1.88(1.11)$ & -0.59 & 0.33 & -1.64 & 0.19 \\
\hline
\end{tabular}

Table 3 Genetic differentiation at the mitochondrial DNA HVR-I D-loop segment ( $\Phi_{\mathrm{ST}}$; above the diagonal) and 12 microsatellite loci ( $F_{\mathrm{ST}}$; below the diagonal) among non-introgressed mtDNA (NI) and introgressed mtDNA European (EU) and North American (NA) L. marinus and $L$. smithsonianus populations

\begin{tabular}{|c|c|c|c|c|}
\hline & $\begin{array}{l}\text { L. marinus (EU, } \\
\text { NI) }\end{array}$ & $\begin{array}{l}\text { L. marinus (NA, } \\
\text { NI) }\end{array}$ & $\begin{array}{l}\text { L. marinus } \\
\qquad(N A, I)\end{array}$ & $\begin{array}{c}\text { L. } \\
\text { smithsonianus }\end{array}$ \\
\hline $\begin{array}{l}\text { L. marinus (EU, } \\
\mathrm{NI} \text { ) }\end{array}$ & - & $0.084 * *$ & $0.713^{* * *}$ & $0.749 * * *$ \\
\hline $\begin{array}{l}\text { L. marinus (NA, } \\
\mathrm{NI} \text { ) }\end{array}$ & $0.034^{*}$ & - & $0.812^{* * *}$ & $0.808^{* * *}$ \\
\hline $\begin{array}{l}\text { L. marinus (NA, } \\
\text { I) }\end{array}$ & 0.037 * & -0.007 & - & $0.071^{* *}$ \\
\hline $\begin{array}{l}\text { L. } \\
\text { smithsonianus }\end{array}$ & $0.237 * * *$ & $0.193^{* * *}$ & $0.169 * * *$ & - \\
\hline
\end{tabular}

L. argentatus (GenBank accession number AJ507814), and we hypothesize that it may have captured it by introgression from this species.

Out of the 49 North American MARINUs individuals included in this study, 57\% possessed a SMI haplotype. Our sample did not allow us to test for geographical variation in the percentage of introgressed birds across America. It is nevertheless noteworthy that the proportion of introgressed individuals among MARINUs chicks $(n=12)$ exceeded $80 \%$ in the breeding colonies of the Sainte-Marie islands located in Eastern Quebec. No specimens identified as SMITHSONIANUS were found carrying a MAR haplotype.

\section{Microsatellites}

Microsatellites diversity and genetic population structure. The amount of genetic variation within species (Table 4) is in line with previous estimates, partly based on the same samples (Crochet et al., 2003). Genetic differentiation between sMithsonIANUs and MARINUs (Table 3) is high compared with other species of large white-headed group (compare with Sonsthagen et al., 2012), again consistent with previous estimates for the same species (Crochet et al., 2003). There was a slight but significant differentiation between North American and European MARINUS, consistent with an expectation of reduced contemporary gene flow.

Significant departures from Hardy-Weinberg equilibrium were detected in the three main populations (SMITHSONIANUS, MARINUS Europe, MARINUS North America) as evidenced by the strongly significant global and positive $F_{\text {IS }}$ value in all three populations (Supplementary Material S1). Such positive $F_{\mathrm{IS}}$ values indicate

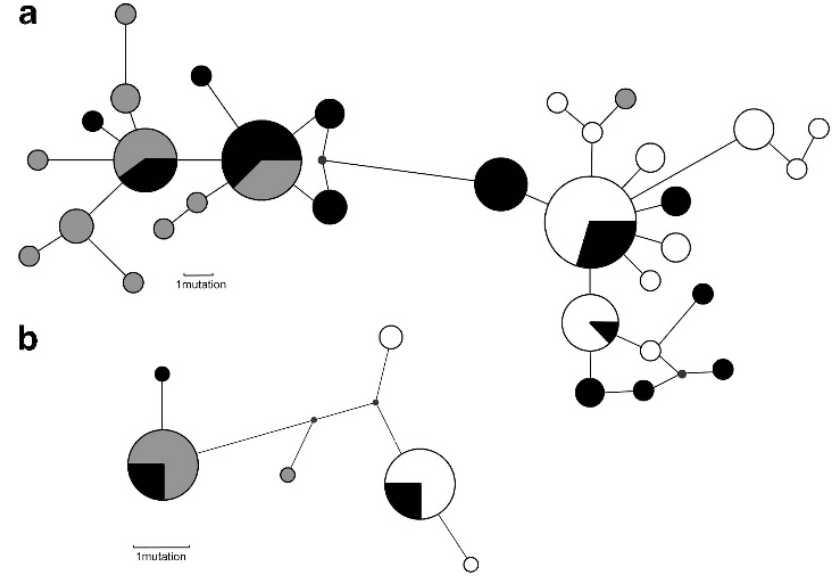

Figure 1 Median-joining networks illustrating relationships among mitochondrial DNA (a) HVR-I of the control region and (b) cyt $b$ haplotypes. European L. marinus haplotypes are shown in grey (HVR-I $n=24$; cyt $b$ $n=24$ ); North American L. marinus haplotypes in black (HVI nonintrogressed $n=21$, introgressed $n=28$; cyt $b$ non-introgressed, $n=11$, introgressed, $n=13$ ) and L. smithsonianus haplotypes in white (HVR-I $n=52$; cyt $b n=40$ ). The size of the node corresponds to the frequency of each haplotype and small black circles represent unsampled haplotypes.

heterozygote deficiencies that can originate from population structure within species (Wahlund effect) but can also be generated by null alleles. Microchecker indeed suggested the presence of null alleles for five of the seven loci that exhibit significant $F_{I S}$ for at least one population (Hg25, Lar12, Hg16, Rbg13 and HG18), which is supported by the high variance among loci for every population (Wahlund effect should show for all loci). As null alleles could affect results of assignment methods, we evaluated their performance by generating multilocus genotypes with the program Hybridlab.

Assignment of simulated individuals. Reliability of assignment by Newhybrids varied as expected, being very good for pure species and F1 hybrids but very poor for backcrosses. Using as classification criterion the category with the highest assignment probability, 90\% of SMITHSONIANUS, $97 \%$ of F1 hybrids and, crucially, 100\% of MARINUS were correctly assigned (see Supplementary Material S2). Backcrosses were correctly identified only in 25\% (backcross with MARINUS) to $35 \%$ (backcross with sMITHSONIANUs) of the simulated genotypes. Misclassified backcrosses were assigned either to F1 hybrids or to the pure species most similar to the backcross type. To sum up, no pure MARINUS was misclassified; F1 hybrids would be readily detectable, but 
only $60 \%$ of backcross with MARINUS were detected as 'non-pure' genotype (F1 or backcross).

Evidence for nuclear introgression. Due to amplification failures, one or more loci were missing for many individuals. The 'full' data set (at most four missing loci) included 104 of the 107 samples individuals, the 'max two missing' data set (at most two missing loci) included 92 individuals and the 'no missing loci' data set included 75 individuals. Both data sets with a variable number of missing data reveal a strong impact of missing data on the performance of the assignment method: effect of the number of missing loci on the assignment probability of MARINUS individuals to MARINUS $\mathrm{F}(50,1)=25.45$, $P<0.00001$ and $\mathrm{F}(41,1)=5.24, P=0.027$ for the 'full' and 'maximum two missing' data sets, respectively.

Most North American MARINUS were assigned to the category pure MARINUS with high probability values (Table 5 , Figures $2 \mathrm{a}$ and $\mathrm{b}$ and Supplementary Material S2). Two individuals from Iles Sainte-Marie (Quebec, Canada) carried SMI haplotypes and were classified as pure SMITHSONIANUS with probability values typical of SMITHSONIANUS. More importantly, their assignment probabilities to either pure MARINUS or MARINUs-backcross were virtually zero. Their positions on the FCA plot (Figure 3, see below) were also completely outside the variation possible in North American MARINUs but fully typical of pure SMITHSONIANUS. As feathers of these two birds were obtained from chicks raised in a mixed colony where the two species bred (Chapdelaine G, personal communication), the most probable explanation for this odd result is a field identification error, and we have therefore removed these two individuals, which were most likely chicks of sMITHSONIANUS, from further analyses.

Table 4 Genetic variation at 12 microsatellites loci genotyped from European (EU) L. marinus, North American (NA) L. marinus (introgressed and non-introgressed individuals) and L. smithsonianus populations: sample size, average number of alleles per locus, observed and expected heterozygosity and $F_{\mathrm{IS}}$ (significance value based on 1000 permutations of alleles within populations)

\begin{tabular}{lcccccr}
\hline Population & $\mathrm{N}$ & Alleles/locus & Ho & He & $\mathrm{F}_{\text {IS }}$ & P-value \\
\hline L. marinus (EU) & 15 & 3.5 & 0.335 & 0.398 & 0.202 & 0.001 \\
L. marinus (NA) & 47 & 5.5 & 0.357 & 0.460 & 0.236 & $<0.001$ \\
L. smithsonianus & 49 & 6.6 & 0.490 & 0.576 & 0.159 & $<0.001$ \\
\hline
\end{tabular}

Table 5 Assignment of individuals (mtDNA non-introgressed (NI); mtDNA introgressed (I)) into one of the following categories: Pure $L$. marinus, Pure L. smithsonianus, first generation hybrid (F1), backcross to MARINUS (BCmar), and backcross to SMITHSONIANUS (BCsmi)

Pure L. marinus Pure L. smithsonianus F1 BCmar BCsmi

$\begin{array}{lrrrrr}\text { L. marinus (EU) } & 9 & 0 & 0 & 0 & 0 \\ \text { L. marinus (NA, NI) } & 16 & 0 & 0 & 0 & 1 \\ \text { L. marinus (NA, I) } & 18 & 2^{\mathrm{a}} & 0 & 0 & 0 \\ \text { L. smithsonianus } & 0 & 43^{\mathrm{b}} & 0 & 0 & 3^{\mathrm{c}}\end{array}$

Assignments are based on 10 microsatellites and individuals with two or fewer missing loci.

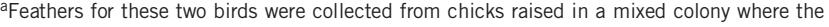
two species bred and likely represent a field sampling error (see text).

bTwo birds, one from Alaska and one from Quebec, were assigned to this category with low PP values $(0.52,0.55)$. All other assignments received high PP values ranging from 0.65 to 0.99 ${ }^{C}$ These three birds were collected in Alaska where hybridization events have been noted between $L$. smithsonianus and other gull species ( $L$. vegae, L. glaucescens). L. marinus does not occur in Alaska.
After removal of the two individuals misidentified in the field, there was no difference in assignment probabilities between European and North American MARINUS for the 'full' data set $(F(50,1)=0.28$, $P=0.602)$ or 'maximum two missing' data set $(\mathrm{F}(41,1)=2.7565$, $P=0.104)$ but a slight difference for the 'no missing loci' data set $(\mathrm{F}(30,1)=4.44, P=0.044)$. In the last case, North American MARINUs have a slightly lower assignment probability to MARINUs than European birds (average assignment probability 0.96 in North America and 0.99 in Europe), with a small number of individuals in North America with rather low assignment probabilities (three individuals with assignment probabilities between 0.65 and 0.82 , see Figure 2 and Supplementary Material S2). Note that the difference in the 'no missing loci' data set is not significant after correcting for multiple tests (that is, the same hypothesis was tested three times).

The first axis of the FCA on microsatellite data differentiated the two species, although a few individuals fall in an area of overlap (Figure 3). As for assignment probabilities, there was no difference in first axis scores between North American and European MARINUs $(\mathrm{F}(50,1)=1.58, P=0.21)$
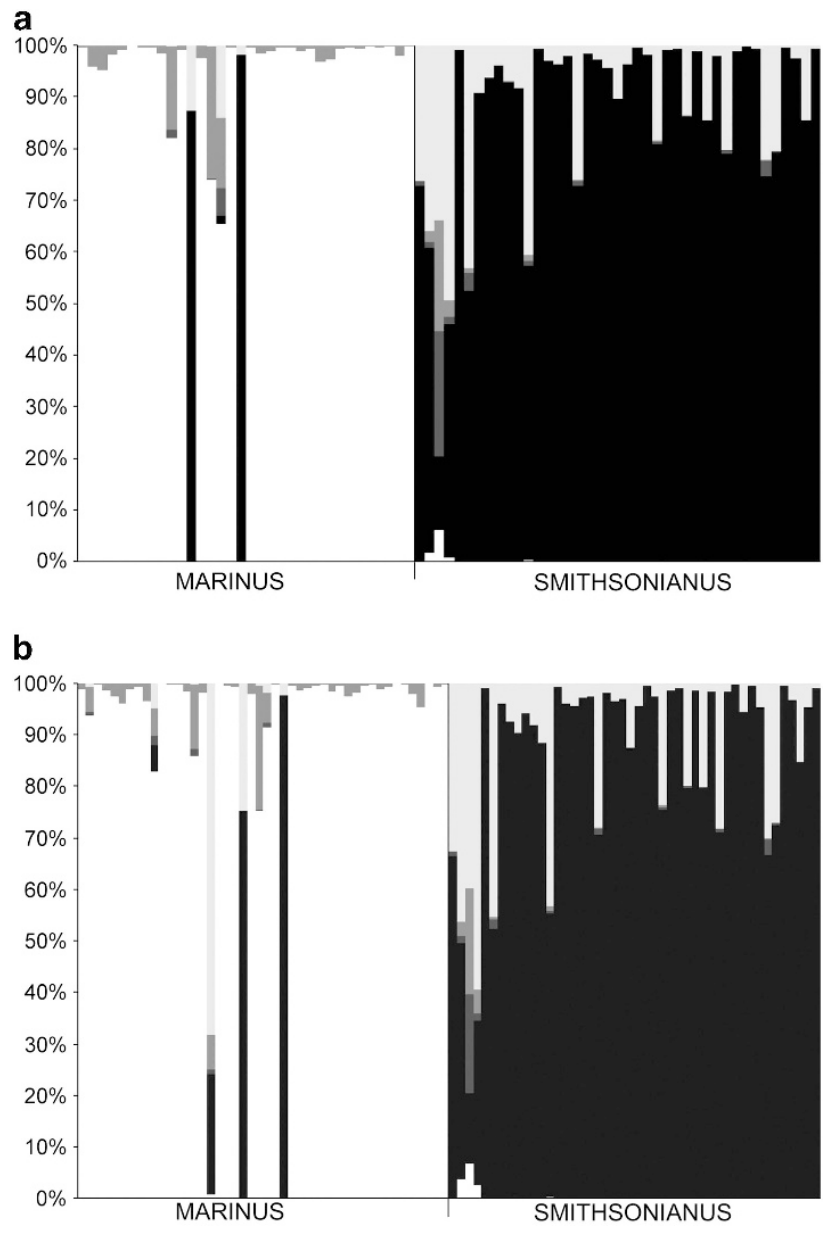

Figure 2 Assignment probabilities of North American L. marinus (mARINUs) and American Herring Gulls (smithsonianus) included in the study to the following categories: Pure L. marinus (marinus; white), Pure L. smithsonianus (smithsonianus; black), first generation hybrid (F1; dark gray), backcross to MARINUS (BCmar; light gray), and backcross to SMITHSONIANus (BCsmi; light gray). Results of analyses of individuals with (a) no missing data at the 10 microsatellite loci and individuals with data (b) missing at two or fewer loci. 


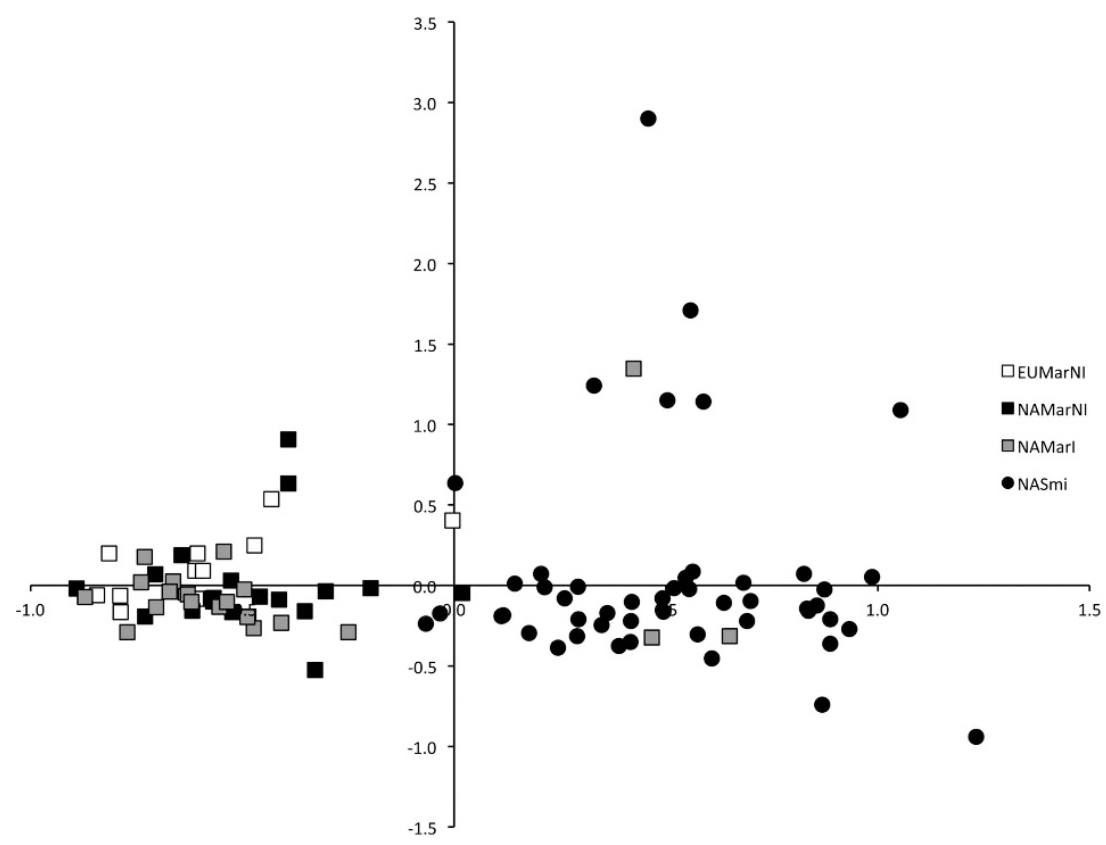

Figure 3 Scatter plot of the two-dimensional FCA performed on non-introgressed European L. marinus (EUMarNI, $n=11$ ), non-introgressed North American L.marinus (NAMarNI, $n=21$ ), mtDNA introgressed L. marinus (NAMarl, $n=20$ ) and $L$. smithsonianus (NASmi, $n=49$ ) individuals based on the 12 microsatellite data set.

Evidence for recent admixture in North America. There was no evidence that MARINUS individuals with the SMI haplotypes differ in nuclear genome from individuals with the MAR haplotype. Within North American MARINUs, the scores along the first axis of the FCA for individuals carrying the SMI mtDNA overlapped fully with individuals carrying the original MAR haplotypes and European birds, and there was no difference in the distribution of the scores of these two groups (analysis of variance: $\mathrm{F}(49,2)=0.87, P=0.43$ ). Accordingly, there was no significant differentiation in microsatellite allelic frequency between North American MARINUs carrying the MAR or SMI haplotypes (Table 3). Thus, we did not detect any evidence that MARINUS individuals with the SMI haplotypes have recent co-ancestry with SMITHSONIANUS.

For examination of individual assignment probabilities, we restrained the data set to individuals with two or fewer missing loci, because individual assignments were unreliable for more incomplete genotypes. For example, two MARINUs from Finland, sampled as fully grown birds by very experienced gull ringers and carrying the typical MAR haplotypes but with four and three missing loci were identified as pure SMITHSONIANUS or backcross with SMITHSONIANUS (SMITHSONIANUS has never been recorded in Finland).

For individuals with two or fewer missing loci, assignment analyses with NewHybrids produced a similar pattern as FCA and $F_{\text {ST }}$ values: most North American MARINUS are assigned to the pure MARINUS category with high probability, and none are identified as F1 or backcross with MARINUs, regardless of which mtDNA lineage they possess. The only exception is a specimen from North Carolina with a MAR haplotype; both FCA scores and assignment probability were incompatible with a pure MARINUS (most likely a backcross to SMITHSONIANUS; assignment probability to backcross with SMITHSONIANUs: 0.68 , to pure SMI: 0.23). Accordingly, there was no difference in assignment probabilities between North American MARINUs carrying the MAR or SMI haplotypes (max. two loci missing: $\mathrm{F}(32,1)=0.84$, $P=0.37$; no missing loci: $\mathrm{F}(24,1)=0.11, P=0.74)$. All smithsonianus individuals were unambiguously classified as pure SMITHSONIANUS, except four birds collected in Alaska (see the 'Methods' section).

\section{DISCUSSION}

Unidirectional introgression of American Herring Gull mitochondria into North American Great Black-backed Gull mirrors mate choice patterns

Mitochondrial lineage sharing between these two species in North America is best explained by unidirectional introgression from L. smithsonianus into L. marinus. First, ancestral polymorphism would result in the sharing of ancestral haplotypes rather than derived haplotypes, as can be seen from Figure 2 in Sternkopf et al. (2010). Second, lineage sharing only occurs in North America where they are sympatric and never in Europe where L. smithsonianus does not occur. As the shared HVR-I and cyt $b$ haplotypes are observed at high frequency in these two species (Crochet et al., 2003, Sternkopf et al., 2010), it is unlikely that the North American MARINus population was introgressed by gull species other than $L$. smithsonianus.

Phenotypic (such as large size) and behavioural (foraging and breeding) differences distinguish $L$. marinus from other members of the Herring Gull complex (Burger and Gochfeld, 1996). Due to these phenotypic and behavioural differences, L. marinus is considered relatively reproductively isolated from co-occurring gull species (Liebers et al., 2004). However, several putative hybrids have been observed on both sides of the Atlantic (L. marinus $\times$ L. argentatus, in Europe or L. marinus $\times$ L. smithsonianus, in Canada: Pierroti, 1987, McCarthy, 2006), suggesting that reproductive barriers between this species and other gull species are still not completely hermetic. Because female preference for larger mates has been observed in several gull species (for example, Tinbergen, 1953, Neubauer et al., 2009 , personal observation), most hybrids are expected to result from the pairing of SMITHSONIANUS females with males of the larger MARINUS. Repeated backcrossing of female hybrids carrying SMITHSONIANUS mtDNA with male MARINUs would introduce SMITHSONIANUS mtDNA 
into MARINUS populations. Conversely, introgression from MARINUs into SMITHSONIANUS (which we did not observe based on haplotypic data) would require pairing of large MARINUs females with smaller SMITHSONIANUS males and subsequent backcrossing of female hybrids with males of the smaller species. Indeed, known heterospecific pairs comprising $L$. smithsonianus and L. marinus always involved a male L. marinus and a female L. smithsonianus (McCarthy, 2006), consistent with the direction of mtDNA introgression observed here.

\section{No nuclear differentiation between individuals carrying introgressed and non-introgressed mtDNA}

If North American MARINUS individuals carrying SMITHSONIANUS mtDNA had acquired these alien (smitHSONIANus) lineages through recent (a few generations ago) hybridizations, we would expect differentiation between individuals carrying the SMI and MAR haplotypes in North America (significant $F_{\mathrm{ST}}$ and differences in FCA scores) and lower assignment probabilities of individuals carrying the SMI haplotype. Differences between MARINUs possessing the SMI and MAR haplotypes were not observed; therefore we conclude that most of the MARINUs individuals carrying SMI haplotypes acquired them through ancient hybridization. The SMI and MAR haplotypes are now segregating in the MARINUs population in North America, with recent hybridization events contributing very little to the lineage sharing of smithsonianus and MARINUs. Three individuals from the mixed colony of Sainte-Marie islands (Quebec, two MARINUS and one SMITHSONIANUS) have relatively low assignment probabilities to their respective species (see Supplementary Material S2). The probability to have this geographic clustering of ambiguous individuals by chance is small and suggests that recent hybridization is likely occurring in this area, albeit resulting in little contribution of haplotype sharing between these two species.

Homoplasy is a well-known drawback of microsatellites; it originates from a combination of high mutation rate and constraint on their evolution, such as size constraint that limit the number of possible repeats (for example, Hedrick, 1999, Balloux et al., 2000). The main effect of such homoplasy is to reduce the level of genetic differentiation between populations. In the case of large white-headed gulls, homoplasy does not seem to contribute much to the low level of divergence between species, as similar levels of divergence have been observed with nuclear markers that are less subject to homoplasy, such as allozymes or AFLP (see Crochet et al., 2003 for more details). However, the important point here is that if homoplasy reduces genetic differentiation between MARINUS and SMITHSONIANUS, it will make the two parental species more difficult to separate but will not affect introgressed individuals differently. Homoplasy could thus explain part of the low genetic divergence between SMITHSONIANUS and MARINUS but not affect any of our conclusions on nuclear introgression, which take into account the limited genetic divergence of the two species.

\section{Extensive introgression of mtDNA from American Herring Gull into Great Black-backed Gull without significant nuclear introgression: evidence of selection of mtDNA variants?} In accordance with the results from Sternkopf et al. (2010), we detected an extensive introgression of mtDNA from SMITHSONIANUS into North American MARINUs. The discrepancy between our observed frequency of SMITHSONIANUS haplotypes into MARINUS (57\%) and the frequency (34\%) of the study from Sternkopf et al. (2010) might result from a simple sampling variance, but it is also possible that there is a geographical variation in SMITHSONIANUs haplotype frequency in MARINUS, with north-westernmost populations harbouring fewer of the introgressed haplotypes. When combining samples from both studies, 37 MARINUS specimens from North America out of the 79 (hence 47\%) carry mitochondria inherited from SMITHSONIANUs parentage.

This extensive mitochondrial introgression is not mirrored by a similar amount of nuclear introgression. Although lack of diagnostic alleles at our suite of nuclear loci precludes equivalent estimation of introgressed alleles frequencies, none of the measures of nuclear introgression indicated a substantial contribution of SMITHSONIANUS alleles to the nuclear gene pool of MARINUS in North America: North American MARINUS were not closer to SMITHSONIANUS than European MARINUs along the FCA axis, and the difference in assignment probabilities was very low and not fully significant after correction for multiple testing. Although we are not aware of any study formally linking genomic admixture and position of individuals along FCA axis (often also called Multiple Correspondence Analysis, see Guinand, 1996) as has been done with Principal Component Analysis (PCA; for example, McVean, 2009), the close analytical similarities of FCA and PCA ensures that admixture would result in a shift of an individual's position on the FCA axis, as it has been observed in several empirical studies (for example, Johanet et al., 2011, Lefebvre et al., 2008). Note that individual genotype data (multiple allelic states at several loci, such as microsatellite data) are not suitable for PCA analyses, hence the use of the FCA here, which is the classical method in this context (Guinand, 1996). Our results thus demonstrate a lack of substantial admixture in the nuclear genome of North American MARINUS, indicating a strong discrepancy in the relative levels of mtDNA and nuclear DNA introgression. In line with the present study, Sternkopf et al. (2010) also observed high levels of mtDNA introgression in Nearctic $L$. marinus individuals from $L$. smithsonianus but were 'unable to discern a shared autosomal genetic component between these two gull taxa', although these results are not shown in their paper. Similar mito-nuclear discordances in the amount of introgression has been documented for a wide range of animal species, in some cases leading to the complete replacement of the mtDNA of the introgressed species by the mtDNA of the other species without any evidence of nuclear introgression (reviewed in Toews and Brelsford, 2012). The pattern we uncovered in North American MARINUS is, for example, similar to the savanna elephant (Loxodonta africana) where mtDNA from the closely related forest elephant (L. cyclotis) reached a high frequency, but none of the three biparentally inherited loci contained any foreign alleles (Roca et al., 2005). Several hypotheses have been proposed to explain such mitonuclear discrepancies in levels of introgression in vertebrates; they can broadly be divided between selective and neutral (demographic) processes (listed in Hedrick, 2010). Demographic processes include unidirectional mating and backcrossing, differential gene flow between organelles and nuclear genes and drift in small populations. Selective hypotheses propose stronger selection against alien nuclear alleles than mitochondrial haplotypes (Funk and Omland, 2003) and positive selection on introgressed mtDNA variants. We will examine these different hypotheses below.

Unidirectional mating and subsequent backcrossing has been invoked to explain some striking instances of discordant mito-nuclear introgression (for example, Roca et al., 2005, see also Hedrick, 2010). As rightly noted by these authors, hybridization of a species A female with a species $B$ male and subsequent backcrossing of female progeny with species B males produce individuals with species A mtDNA but with essentially species B nuclear background, because the ancestry of species $\mathrm{A}$ in the nuclear genome halves at each generation of backcrossing. This phenomenon, however, is unable to account for extensive mtDNA introgression without comparable nuclear 
introgression. The frequency of the alien mtDNA in the introgressed species would remain very low unless there is sufficient mtDNA gene flow to result in an increase of the alien mtDNA frequency. Such substantial female-mediated gene flow would inevitably have consequences on the frequency of alien nuclear alleles (as females transmit both mtDNA and nuclear DNA). Unidirectional mating and subsequent backcrossing thus explains unidirectional gene flow between species (in our case, the introgression of SMITHSONIANUS in MARINUS but not the reverse) but is not sufficient alone to explain how SMITHSONIANUS mtDNA has reached such high frequency in MARINUS populations without detectable nuclear introgression.

Random drift in small populations, combined with unidirectional backcrossing, could generate the pattern we observe, however. Although the chances to observe the SMITHSONIANUS mitochondria rise in frequency by chance in a large population of MARINUs are remote, several generations of backcrossing of female hybrids in MARINUS (thus creating individuals carrying the SMITHSONIANUS mtDNA with an essentially MARINUS nuclear background) in a very small population of MARINUS (thus making initial frequency of SMITHSONIANUS mitochondria larger) could probably result in a large frequency of SMITHSONIANUS mtDNA in an otherwise 'pure' MARINUS population. Hudson and Turelli (2003) have recently shown that the differential effect of drift on mitochondrial and nuclear genomes is even stronger than that suggested by their difference in effective population size, which could arguably make this scenario more likely.

Sex-biased gene flow is unlikely to explain strong cases of mitonuclear discordance, for the same reason as above, unless sex-biases in dispersal are extreme. If females disperse very little but males of species B move readily to the range of species A, they could theoretically 'swamp' the nuclear genome of species A while species A mitochondrial would remain in situ. Such extreme sex-biases in dispersal are rare in birds (outside of Anseriformes), and both SMITHSONIANUS and MARINUS CO-occur in North America, therefore this scenario does not account for our results. A related hypotheses has been posited by Currat et al. (2008) (see also Excoffier et al., 2009): in case of range expansion where one species invades the distribution of another species, these authors have shown by simulation that genetic introgression largely occurs from the resident into the invading species and that introgression is stronger when intraspecific gene flow is reduced. These results led them to propose that reduced gene flow of mitochondrial DNA relative to nuclear DNA (a combination of smaller effective size for mtDNA and, when relevant, sex-biased dispersal, see Birky et al., 1983; Crochet, 2000) could generate a higher level of introgression for uniparentally inherited markers. The fact that introgression was detected from the resident sMITHSONIANUs to the more recent colonizer (MARINUS, see Sternkopf et al., 2010) fits this scenario well. However, we argue this scenario should be evaluated by explicit modeling of nuclear and mitochondrial introgression under the same demographic parameters before it can be regarded as fully supported. In our species, where females should have a greater tendency for dispersal than males (Greenwood, 1980), it is unclear whether mitochondrial gene flow would remain reduced compared with nuclear gene flow or if female-biased dispersal would be sufficient to counter the effect of smaller effective size of the mitochondria and equilibrate levels of nuclear and mitochondrial gene flow between species.

An alternative hypothesis to explain strong discordance in the level of mitochondrial and nuclear introgression invokes stronger negative selection of nuclear alleles in the genome of an alien species compared with mtDNA. As noted by several authors, 'mitochondrial alleles might be expected to introgress farther, on average, than nuclear loci if their persistence in a foreign gene pool is less constrained by linkage to selected loci than are the alleles of nuclear genes' (Funk and Omland, 2003). In large white-headed gulls, including smithsONIANUS and MARINUS, evidence of selection on the nuclear genome is lacking, and what data available suggest is that species cohesion is largely maintained by selection on a small number of loci likely influencing phenotype, with most neutral markers experiencing weak barriers to gene flow (Gay et al., 2009). Therefore, direct selection against alien alleles is unlikely to explain the limited signal of introgression at putatively neutral microsatellite markers based on the hypothesis by Gay et al. (2009), as gene flow at most neutral nuclear markers should not be directly counter selected.

Positive selection of alien mitochondria in the nuclear background of another species is increasingly proposed as a possible explanation for strong mito-nuclear biases in introgression (see Toews and Brelsford, 2012). It has been hypothesized that high mtDNA introgression rate, sometimes leading to the complete replacement of the specific mtDNA lineages in the introgressed species, may happen if selection favours some mtDNA variants that are better adapted to local conditions (see Ballard and Whitlock, 2004 for a review). Our failure to reject the selective neutrality of SMITHSONIANUS haplotypes found in introgressed L. marinus populations does not necessarily contradict this hypothesis: these tests detect the loss of diversity due to the increase in frequency of a given haplotype through selective processes and are sensitive to demographic processes. In the case of locally adapted mtDNA, the entire population of mitochondria would have a selective advantage, and there is no reason to expect a significant loss of genetic diversity unless the initial number of hybridization events was very low. The selective pressure generally invoked to explain differences in the fitness of mtDNA variants is most often related to external temperatures (Drosophila: Matsuura et al., 1993; mammals: Ballard and Whitlock, 2004; Fink et al., 2004; Ropiquet and Hassanin, 2006; Melo-Ferreira et al., 2009; fish: Wilson and Bernatchez, 1998; reptiles: Heulin et al., 2011). Indeed, MARINUS in western Europe and northeastern North America experience very different climatic niches (much colder winter in North America, Seager et al., 2002) and therefore may explain the pattern of introgression observed here.

\section{CONCLUSION}

It has been proposed that nuclear introgression should be higher than mtDNA introgression in birds, because markers associated with the dispersing sex (usually females in birds) should be less prone to introgression (Petit and Excoffier, 2009). Indeed, all case studies of birds listed in Petit and Excoffier (2009) support this prediction. Females being the heterogametic sex in birds, Haldane's rule would also predict that mitochondrial haplotypes show patterns of reduced introgression compared with nuclear alleles (Carling and Brumfield, 2008). However, several cases of interspecific gene flow documented in birds depicted the reverse pattern; no nuclear introgression is detected while the maternally transmitted mtDNA exhibits high levels of introgression (Tejedor et al., 2007; Bellemain et al., 2008; Irwin et al., 2009). This is the same pattern we observed between the North American L. marinus and the sympatric L. smithsonianus. Fitness data (clutch volume, hatching success) suggest that Haldane's rule does not apply to $L$. argentatus and $L$. cachinnans, two closely related gull species hybridizing in Europe (Neubauer et al., 2009). Similarly to MARINUS and SMITHSONIANUS, these two species of recent origin exhibit a low level of genetic divergence. In contrast with other organisms, birds are often able to produce fertile hybrids even at relatively high levels of genetic distance (Price and Bouvier, 2002). This characteristic may explain why in several hybridizing bird species maternally 


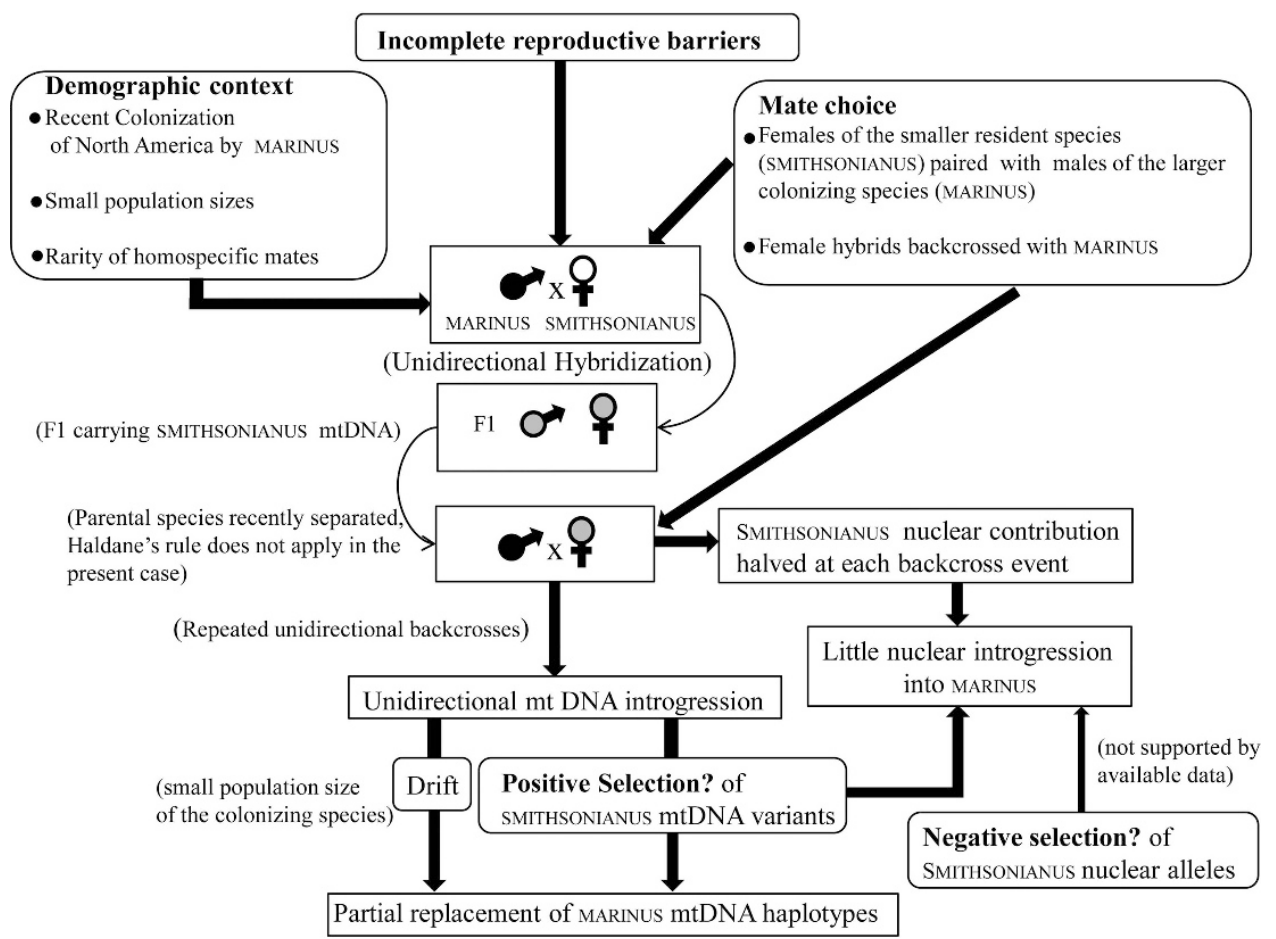

Figure 4 Schematic representation of demographic and selective mechanisms that may explain mito-nuclear and asymmetric introgression patterns resulting from past hybridization events between L. marinus and L. smithsonianus. Among alternative neutral explanations, only drift in small populations and asymmetric mate choice in an invasive context are consistent with our data. We were unable to demonstrate selection as the main cause of mito-nuclear introgression discordance but cannot dismiss the possible role of selection on mtDNA in the observed pattern. As it is generally difficult to assess the role of selection in patterns of introgression observed in natural populations, we advocate that evaluating alternative neutral hypotheses may help to indirectly support or reject hypotheses based on selective processes.

inherited mtDNA shows higher levels of introgression than autosomal markers in contrast with Haldane's rule predictions.

Additionally, studies proposing direct selection on mitochondrial variants driven by local climatic adaptation are increasingly reported in various organisms (see above), including birds (Cheviron and Brumfield, 2009; Ribeiro et al., 2011). This led Rheindt and Edwards (2011) to suggest that adaptive introgression is an underappreciated process shaping patterns of mtDNA diversity within, and differentiation between, avian species. As we have discussed above, we were unable to support selection as the cause of discordant mito-nuclear introgression in our species, but we could dismiss most of the alternative scenario invoking neutral, demographic processes. Only drift in small populations and biased introgression as a result of unequal gene flow in an invasion context remain as a possible demographic explanation (see Figure 4).

It will often be difficult to demonstrate that selection was the causal mechanism of mtDNA introgression unless there are obvious signs of selective sweeps. In our case, we have been unable to discriminate between several alternative scenarios, including drift in a small population, effects of different levels of gene flow or positive selection of introgressed mitochondrial variants. However, we suggest that researchers carefully evaluate the alternative demographic neutral scenarios that have been proposed to explain strongly discordant patterns of mitochondrial and nuclear introgression and that several verbal models advanced in previous studies need validation via more formal approaches before being considered as valid explanations. Possible future developments include explicit modelling of mitochondrial and nuclear introgression in individual-based simulations under the various demographic scenarios discussed above, with nuclear markers either linked to loci under divergent selection ('speciation loci') or not. Another much needed study is how selection on the whole mitochondrial diversity of one species into the nuclear background of the other species (as opposed to the classical effects of selection on mutational variants of mtDNA) affects patterns of diversity in the population of selected mitochondria. If most of the suggested neutral scenarios are unable to explain extensive mitochondrial introgression without substantial nuclear gene flow, we feel this will provide increased support for hypotheses invoking selective processes as the mechanisms promoting patterns of discordant rates of mito-nuclear introgression.

\section{DATA ARCHIVING}

Mitochondrial haplotypes were deposited in Genbank (accession numbers KF422942-KF422973). Microsatellite data were deposited in DRYAD (doi:10.5061/dryad.f789n).

\section{CONFLICT OF INTEREST}

The authors declare no conflict of interest.

\section{ACKNOWLEDGEMENTS}

We are very grateful to R Barret, R Bradbury, B Cadiou (Bretagne vivante, SEPNB), J Dean (National Museum of Natural History), D Dittmann (Louisiana State University Museum of Natural Science), G Chapdelaine and J-F Rail (Service Canadien de la Faune) R Evans, A Forsten, G Fox, D Mourier, M Robbins (Kansas Natural History Museum), V Rauste, P Sweet (American Museum of Natural History), N Rice (Academy of Natural Sciences of Philadelphia) and P Yésou for kindly providing us tissue samples. HYBRIDLAB is currently difficult to find in the internet as the links provided in the original 
publication are broken; S Consuegra, EE Nielsen, U Saarma and RA SánchezGuillén helped us in various ways to obtain this program. Laboratory assistance was provided by C Bonillo, J Lambourdière and A Tillier at MNHN and J Hunt and L Weight (Laboratories of Analytical Biology, Smithsonian Institution). We thank Daniel Pons who helped to draw the Figure 1 as well as Bailey D McKay and three anonymous referees for helpful comments on an earlier version of the manuscript. Part of this research was funded through an interagency agreement between the Smithsonian and the FAA.

Anderson E C, Thompson EA (2002). A model-based method for identifying species hybrids using multilocus genetic data. Genetics 160: 1217-1229.

Andrle RF (1972). Another probable hybrid of Larus marinus and Larus argentatus. Auk 89: 669-671.

Ballard JWO, Whitlock MC (2004). The incomplete natural history of mitochondria. Mol Ecol 13: 729-744.

Balloux F, Brünner H, Lugon-Moulin N, Hausser J, Goudet J (2000). Microsatellites can be misleading: an empirical and simulation study. Evolution 54: 1414-1422.

Bandelt HJ, Forster P, Rohl A (1999). Median-joining networks for inferring intraspecific phylogenies. Mol Biol Evol 16: 37-48.

Barton NH, Gale KS (1993). Genetic analysis of hybrid zones. In: Hybrid Zones and the Evolutionary ProcessHarrison RG (ed). Oxford University Press: Oxford, UK, pp 13-45.

Barton NH, Hewitt GM (1985). Analysis of hybrid zones. Annu Rev Ecol Syst 16: 113-148.

Belkhir K, Borsa P, Chikhi L, Raufaste N, Bonhomme F (1996-2004). GENETIX 4.05, logiciel sous Windows TM pour la génétique des populations. Laboratoire Génome, Populations, Interactions, CNRS UMR 5171, Université de Montpellier II, Montpellier, France. Available at http://kimura.univ-montp2.fr/genetix/.

Bell DA (1997). Hybridization and reproductive performance in gulls of the Larus glaucescens-occidentalis complex. Condor 99: 585-594.

Bellemain E, Bermingham E, Ricklefs RE (2008). The dynamic evolutionary history of the bananaquit (Coereba flaveola). BMC Evol Biol 8: 240.

Birky CW Jr., Maruyama T, Fuerst P (1983). An approach to population and evolutionary genetic theory for genes in mitochondria and chloroplasts, and some results. Genetics 103: 513-527

Burger AE, Gochfeld M (1996). Family Laridae.. In: del Hoyo J, Elliott A, Sargatal J (eds). Handbook of the Birds of the World vol. 3,, Hoatzin to Auks Lynx Edicions: Barcelona, Spain, pp 572-563.

Carling MD, Brumfield RT (2008). Haldane's rule in an avian system: using cline theory and divergence population genetics to test for differential introgression of mitochondrial, autosomal, and sex-linked loci across the passerina bunting hybrid zone. Evolution 62: 2600-2615.

Cheviron ZA, Brumfield RT (2009). Migration-selection balance and local adaptation of mitochondrial haplotypes in Rufous-collared Sparrows (Zonotrichia capensis) along an elevational gradient. Evolution Int J Org Evolution 63: 1593-1605.

Crochet P-A (2000). Genetic structure of avian populations-allozymes revisited. Mol Eco 9: $1463-1469$

Crochet P-A, Chen JJZ, Pons J-M, Lebreton J-D, Hebert PDN, Bonhomme F (2003). Genetic differentiation at nuclear and mitochondrial loci among large white-headed gulls: sex-biased interspecific gene flow? Evolution Int J Org Evolution 57: 2865-2878.

Crochet P-A, Lebreton J-D, Bonhomme F (2002). Systematics of large white-headed gulls: patterns of mitochondrial DNA variation in western European taxa. Auk 119: 603-620.

Currat M, Ruedi M, Petit RJ, Excoffier L (2008). The hidden side of invasions: massive introgression by local genes. Evolution Int J Org Evolution 62: 1908-1920.

de Knijff PF, Denkers F, van Swelm ND, Kuipier M (2001). Genetic affinities within the herring gull Larus argentatus assemblage revealed by AFLP genotyping. J Mol Evol 52: 85-93.

Excoffier L, Foll M, Petit RJ (2009). Genetic consequences of range expansions. Annu Rev Ecol Syst 40: 481-501.

Excoffier L, Laval G, Schneider S (2005). Arlequin version 3.0: An integrated software package for population genetics data analysis. Evol Bioinformatics Online 1: 47-50.

Fink S, Excoffier L, Heckel G (2004). Mitochondrial gene diversity in the common vole Microtus arvalis shaped by historical divergence and local adaptations. $\mathrm{Mol} E \mathrm{Co} / 13$ : 3501-3514.

Fu YX (1997). Statistical tests of neutrality of mutations against population growth, hitchhiking and background selection. Genetics 147: 915-925.

Funk DJ, Omland KE (2003). Species-level paraphyly and polyphyly: frequency, causes, and consequences, with insights from animal mitochondrial DNA. Annu Rev Ecol Syst 34: 397-423.

Gay L, Neubauer G, Zagalska-Neubauer M, Debain C, Pons JM, David P et al. (2007). Molecular and morphological patterns of introgression between two large white-headed gull species in a zone of recent secondary contact. Mol Ecol 16: 3215-3227.

Gay L, Neubauer G, Zagalska-Neubauer M, Pons J-M, Bell DA, Crochet P-A (2009). Speciation with gene flow in the large white-headed gulls: does selection counterbalance introgression? Heredity 102: 133-146.

Given AD, Mills JA, Baker AJ (2002). Isolation of polymorphic microsatellite loci from the red-billed gull (Larus novaehollandiae scopulinus) and amplification in related species. Mol Ecol Notes 2: 416-418.
Good JM, Hird S, Reid N, Demboski JR, Steppan SJ, Martin-Nims TR et al. (2008). Ancient hybridization and mitochondrial capture between two species of chipmunks. Mol Ecol 17: 1313-1327.

Good TP (2002). Breeding success in the Western gull $\times$ Glaucous-winged gull complex: the influence of habitat and nest-site characteristics. Condor 104: 353-365.

Good TP, Ellis JC, Annett CA, Pierotti R (2000). Bounded hybrid superiority in an avian hybrid zone: effects of mate, diet, and habitat choice. Evolution Int J Org Evolution 54: 1774-1783.

Grant PR, Grant BR (1992). Hybridization of bird species. Science 256: 193-197.

Greenwood PJ (1980). Mating systems, philopatry and dispersal in birds and mammals. Anim Behav 28: 1140-1162.

Gregory SM, Quinn JS (2006). Microsatellite isolation from four avian species comparing two isolation techniques. Mol Ecol Notes 6: 87-89.

Guinand B (1996). Use of a multivariate model using allele frequency distributions to analyse patterns of genetic differentiation among populations. Biol J Linn Soc 58: 173-195.

Hall TA (1999). BioEdit: a user-friendly biological sequence alignment editor and analysis program for Windows 95/98/NT. Nucleic Acids Symp Ser 41: 95-98.

Hedrick PW (1999). Perspective: highly variable loci and their interpretation in evolution and conservation. Evolution 53: 313-318.

Hedrick PW (2010). Cattle ancestry in bison: explanations for higher mtDNA than autosomal ancestry. Mol Ecol 19: 3328-3335.

Heulin B., Surget-Groba Y, Sinervo B, Miles D, Guiller A (2011). Dynamics of haplogroup frequencies and survival rates in a contact zone between two mtDNA lineages of the lizard Lacerta vivipara. Ecography 34: 436-447.

Hoffman W, Wiens JA, Scott JM (1978). Hybridization between gulls (Larus glaucescens and L. occidentalis) in the Pacific Northwest. Auk 95: 441-458.

Hudson RR, Turelli M (2003). Stochasticity overrules the 'three-times rule': genetic drift, genetic draft, and coalescence times for nuclear loci versus mitochondrial DNA. Evolution 57: 182-190.

Irwin DE, Rubtsov AS, Panov EN (2009). Mitochondrial introgression and replacement between yellowhammers (Emberiza citrinella) and pine buntings (Emberiza leucocephalos) (Aves: Passeriformes). Biol J Linn Soc 98: 422-438.

Jehl JR (1960). A probable hybrid of Larus argentatus and L. marinus. Auk 77: 343-345.

Johanet A, Secondi J, Lemaire C (2011). Widespread introgression does not leak into allotopy in a broad sympatric zone. Heredity 106: 962-972.

Kimura M (1980). A simple method for estimating evolutionary rate of base substitution through comparative studies of nucleotide sequences. J Mol Evol 16: 111-120.

Lefebvre T, Châline N, Limousin D, Dupont S, Bagnères A-G (2008). From speciation to introgressive hybridization: the phylogeographic structure of an island subspecies of termite, Reticulitermes lucifugus corsicus. BMC Evol Biol 8: 38.

Liebers D, de Knijff P, Helbig AJ (2004). The herring gull complex is not a ring species. Proc R Soc Lond Ser B Biol Sci 27: 893-901.

Liebers D, Helgig A, de Knijff P (2001). Genetic differentiation and phylogeography of gulls in the Larus cachinnans-fuscus group (Aves: Charadriiformes). Mol Ecol 10: 2447-2462.

uttikhuizen PC, Drent J, Peijnenburg KTC, van der Veer HW, Johannesson K (2012). Genetic architecture in a marine hybrid zone: comparing outlier detection and genomic clines analysis in the bivalve Macoma balthica. Mol Ecol 21: 3048-3061.

Mallet J (2005). Hybridization as an invasion of the genome. Trends Ecol Evol 20: 229-237.

Matsuura ET, Niki Y, Chigusa SI (1993). Temperature-dependent selection in the transmission of mitochondrial DNA in Drosophila. Japenese J Genet 68: 127-135.

McCarthy EM (2006). Handbook of Avian Hybrids of the World. Oxford University Press: Oxford, UK.

McVean G (2009). A genealogical interpretation of principal components analysis. PLoS Genet 5: e1000686.

Melo-Ferreira JM, Alves PC, Freitas H, Ferrand N, Boursot P (2009). The genomic legacy from the extinct Lepus timidus to the three hare species of Iberia: contrast between mtDNA, sex chromosomes and autosomes. Mol Ecol 18: 2643-2658.

Neubauer G, Zaglaska-Neubauer M, Pons J-M, Crochet P-A., Chylarecky P, Przystalski A et al. (2009). Assortative mating without complete reproductive isolation in a zone of recent secondary contact between herring gulls (Larus argentatus) and Caspian gulls (L. cachinnans). Auk 126: 409-419.

Nielsen EE, Bach LA, Kotlicki P (2001). HYBRIDLAB (version 1.0): a program for generating simulated hybrids from population samples. Mol Ecol Notes 6: 971-973.

Olsen KM, Larsson H (2004). Gulls of Europe, Asia and North America. Chistopher Helm: London, UK.

Petit RJ, Excoffier L (2009). Gene flow and species delimitation. Trends Ecol Evol 24: 386-393.

Pierotti R (1987). Isolating mechanisms in seabirds. Evolution 41: 559-570.

Pinho C, Hey J. (2010). Divergence with gene flow: models and data. Annu Rev Ecol Syst 41: 215-230.

Pons JM, Crochet PA, Thery M, Bermejo A (2004). Geographical variation in the yellowlegged gull: introgression or convergence from the herring gull? J Zool Syst Evol Res 42 245-256.

Posada D, Crandall KA (2001). Intraspecific phylogenetics: trees grafting into networks. Trends Ecol Evol 16: 37-45.

Price TD, Bouvier MM (2002). The evolution of F1 postzygotic incompatibilities in birds. Evolution 56: 2083-2089.

Renoult JP, Geniez P, Bacquet P, Benoit L, Crochet PA (2009). Morphology and nuclear markers reveal extensive mitochondrial introgressions in the Iberian Wall Lizard species complex. Mol Ecol 18: 4298-4315. 
Rheindt FE, Edwards SV (2011). Genetic introgression: an integral but neglected component of speciation in birds. Auk 128: 620-632.

Ribeiro A, Lloyd P, Bowie RCK (2011). A tight balance between natural selection and gene flow in a southern African arid-zone endemic bird. Evolution Int J Org Evolution 65: 3499-3514.

Rice AM, Rudh A, Ellegren H, Qvarnström A (2011). A guide to the genomics of ecological speciation in natural animal populations. Ecol Lett 14: 9-18.

Roca AL, Georgiadis N, O'Brien SJ (2005). Cytonuclear genomic dissociation in African elephant species. Nat Genet 37: 96-100.

Ropiquet A, Hassanin A (2006). Hybrid origin of the Pliocene ancestor of wild goats. Mol Phyl Evol 41: 395-404.

Seager R, Battisti DS, Yin J, Gordon N, Naik N, Clement AC et al. (2002). Is the Gulf Stream responsible for Europe's mild winters? Q J R Meteorological Soc 128: 2563-2586.

She J-X, Autem M, Kotoulas G, Pasteur N, Bonhomme F (1987). Multivariate analysis of genetic exchanges between Solea aegyptiaca and Solea senegalensis (Teleosts, Soleidae). Biol J Linn Soc 32: 357-371.

Sonsthagen SA, Chesser RT, Bell DA, Dove CJ (2012). Hybridization among Arctic whiteheaded gulls (Larus spp.) obscures the genetic legacy of the Pleistocene. Ecol Evol 2: 1278-1295.

Steeves TE, Maloney RF, Hale ML, Tylianakis JM, Gemmell NJ (2010). Genetic analyses reveal hybridization but no hybrid swarm in one of the world's rarest birds. $\mathrm{Mol} E \mathrm{col} 19$. 5090-5100.

Sternkopf V, Liebers-Helbig D, Ritz MS, Zang J, Helbig AJ, de Knijff P (2010). Introgressive hybridization and the evolutionary history of the herring gull complex revealed by mitochondrial and nuclear DNA. BMC Evol Biol 10: 348.
Tajima F (1989). Statistical method for testing the neutral mutation hypothesis by DNA polymorphism. Genetics 123: 585-595.

Tejedor MT, Monteagudo LV, Mautner S, Hadjisterkotis E, Arruga MV (2007). Introgression of Alectoris chukar genes into a Spanish wild Alectoris rufa population. J Hered 98: 179-182.

Tinbergen N (1953). The Herring Gull's World. Williams Collins and Co Ltd: London, UK.

Tirard C, Helfenstein F, Danchin E (2002). Polymorphic microsatellites in the black-legged kittiwake Rissa tridactyla. Mol Ecol Notes 2: 431-433.

Toews DPL, Brelsford A (2012). The biogeography of mitochondrial and nuclear discordances in animals. Mol Ecol 21: 3907-3930.

van Oosterhout C, Hutchinson WF, Wills DPM, Shipley P (2004). MICRO-CHECKER: software for identifying and correcting genotyping errors in microsatellite data. Mol ECO Notes 4: 535-538.

Vigfúsdóttir F, Pálsson S, Ingólfsson A (2008). Hybridization of glaucous gull (Larus hyperboreus) and herring gull (Larus argentatus) in Iceland: mitochondrial and microsatellites data. Phil Trans $R$ Soc B 363: 2851-2860.

Williamson FSL, Peyton LJ (1963). Interbreeding of Glaucous-winged and Herring Gulls in the Cook Inlet Region, Alaska. Condor 65: 24-28.

Wilson CC, Bernatchez L (1998). The ghost of hybrid past: fixation of arctic char (Salvelinus alpinus) mitochondrial DNA in an introgressed population of lake trout S. namaycush). Mol Ecol 7: 127-132.

Zieliński P, Nadachowska-Brzyska K, Wielstra B, Szkotak R, Cogălniceanu SD, Babik W (2013). No evidence for nuclear introgression despite complete mtDNA replacement in the Carpathian newt (Lissotriton montandoni). Mol Ecol 22 1884-1903.

Supplementary Information accompanies this paper on Heredity website (http://www.nature.com/hdy)

\section{APPENDIX 1: INFORMATION ON SPECIMENS INCLUDED IN THE STUDY; LOCALITIES, COLLECTORS, INSTITUTIONS AND GENETIC MARKERS AVAILABLE FOR EACH SPECIMEN}

\begin{tabular}{|c|c|c|c|c|c|c|c|c|}
\hline $\begin{array}{l}\text { Specimen } \\
\text { number }\end{array}$ & Tissue number & Species & Group & Localities & Collector, Institution & HVR-I & Cyt b & Microsatellites \\
\hline Mari490 & PAC 547 & L. marinus & $m A$ & Staten Island, New York, USA & AMNH & $\mathrm{H} 19$ & $\mathrm{H} 1$ & Yes \\
\hline Mari491 & PRS 337 & L. marinus & $m A$ & JFK Airport, New York, USA & AMNH & H19 & $\mathrm{H} 1$ & Yes \\
\hline Mari493 & PRS 1317 & L. marinus & $m A$ & JFK Airport, New York, USA & AMNH & $\mathrm{H} 19$ & $\mathrm{H} 1$ & Yes \\
\hline Mari492 & PRS 319 & L. marinus & $m A$ & JFK Airport, New York, USA & AMNH & $\mathrm{H} 19$ & $\mathrm{H} 1$ & Yes \\
\hline Mari494 & PEP S-51 & L. marinus & $m A$ & North Carolina, USA & AMNH & $\mathrm{H} 21$ & $\mathrm{H} 1$ & Yes \\
\hline Mari6162 & 6162 & L. marinus & $m A$ & Wachreague Inlet, Virginia, USA & ANSP & $\mathrm{H} 20$ & $x$ & Yes \\
\hline Mari438 & 13396 & L. marinus & $m A$ & Louisiana, USA & Donna Dittmann, LSUMZ & $\mathrm{H} 19$ & $\mathrm{H} 1$ & Yes \\
\hline Mari442 & 6749 & L. marinus & $m A$ & Louisiana, USA & Donna Dittmann, LSUMZ & $\mathrm{H} 19$ & $\mathrm{H} 1$ & Yes \\
\hline Mari435 & 16342 & L. marinus & $m A$ & Maine, USA & Donna Dittmann, LSUMZ & $\mathrm{H} 21$ & $\mathrm{H} 1$ & Yes \\
\hline Mari249 & MNHN249 & L. marinus & $m A$ & Iles Sainte-Marie, Quebec & $\begin{array}{l}\text { Gilles Chapdelaine, Jean-François } \\
\text { Rail, SCF }\end{array}$ & $\mathrm{H} 19$ & $\mathrm{H} 1$ & Yes \\
\hline Mari255 & MNHN255 & L. marinus & $m A$ & Iles Sainte-Marie, Quebec & $\begin{array}{l}\text { Gilles Chapdelaine, Jean-François } \\
\text { Rail, SCF }\end{array}$ & $\mathrm{H} 23$ & $\mathrm{H} 1$ & Yes \\
\hline Mari16342 & 16342 & L. marinus & $m A$ & Maine, USA & LSUMZ & $\mathrm{H} 21$ & $x$ & Yes \\
\hline Mari503 & MNHN503 & L. marinus & $m A$ & Smithville, Missouri, USA & Mark Robbins, KNHM & $\mathrm{H} 29$ & $\mathrm{H} 2$ & Yes \\
\hline Mari28 & USNM638661 & L. marinus & $m A$ & Maryland, USA & NMNH & H19 & $x$ & Yes \\
\hline Mari30 & USNM638663 & L. marinus & $m A$ & Maryland, USA & NMNH & $\mathrm{H} 19$ & $x$ & Yes \\
\hline Mari23 & USNM638693 & L. marinus & $m A$ & Maryland, USA & NMNH & $\mathrm{H} 22$ & $x$ & Yes \\
\hline Mari08 & USMN641193 & L. marinus & $m A$ & JFK Airport, New York, USA & NMNH & $\mathrm{H} 19$ & $x$ & Yes \\
\hline Mari01 & USMN641190 & L. marinus & $m A$ & JFK Airport, New York, USA & NMNH & $\mathrm{H} 2 \mathrm{O}$ & $x$ & Yes \\
\hline Mari02 & USMN641184 & L. marinus & $m A$ & JFK Airport, New York, USA & NMNH & $\mathrm{H} 2 \mathrm{O}$ & $x$ & Yes \\
\hline Mari05 & USMN641188 & L. marinus & $m A$ & JFK Airport, New York, USA & NMNH & $\mathrm{H} 20$ & $x$ & Yes \\
\hline Mari09 & USMN641187 & L. marinus & $m A$ & JFK Airport, New York, USA & NMNH & $\mathrm{H} 22$ & $x$ & Yes \\
\hline Mari9359 & DOT9359 & L. marinus & mAint & JFK Airport, New York, USA & AMNH & $\mathrm{H} 10$ & $x$ & Yes \\
\hline Mari9360 & DOT9360 & L. marinus & mAint & JFK Airport, New York, USA & AMNH & H3 & $x$ & Yes \\
\hline Mari10092 & DOT10092 & L. marinus & mAint & JFK Airport, New York, USA & AMNH & H3 & $x$ & Yes \\
\hline Mari6148 & 6148 & L. marinus & mAint & Wachreague Inlet, Virginia, USA & ANSP & $\mathrm{H} 10$ & $x$ & $x$ \\
\hline Mari6140 & 6140 & L. marinus & mAint & Wachreague Inlet, Virginia, USA & ANSP & $\mathrm{H} 7$ & $x$ & Yes \\
\hline Mari51712 & 51712 & L. marinus & mAint & Wantry Island, New York, USA & Cornell Laboratory of Ornithology & $\mathrm{H} 6$ & $x$ & $x$ \\
\hline Mari444 & 16341 & L. marinus & mAint & Maine, USA & Donna Dittmann, LSUMZ & $\mathrm{H} 1$ & $\mathrm{H} 5$ & Yes \\
\hline Mari434 & 8664 & L. marinus & mAint & North Carolina, USA & Donna Dittmann, LSUMZ & $\mathrm{H} 1$ & $\mathrm{H} 5$ & Yes \\
\hline
\end{tabular}


Appendix 1 (Continued)

\begin{tabular}{|c|c|c|c|c|c|c|c|c|}
\hline $\begin{array}{l}\text { Specimen } \\
\text { number }\end{array}$ & Tissue number & Species & Group & Localities & Collector, Institution & $H V R-I$ & Cyt b & Microsatellites \\
\hline Mari250 & MNHN250 & L. marinus & mAint & Iles Sainte-Marie, Quebec, Canada & $\begin{array}{l}\text { Gilles Chapdelaine, Jean-François } \\
\text { Rail, SCF }\end{array}$ & $\mathrm{H} 1$ & H5 & Yes \\
\hline Mari251 & MNHN251 & L. marinus & mAint & Iles Sainte-Marie, Quebec, Canada & $\begin{array}{l}\text { Gilles Chapdelaine, Jean-François } \\
\text { Rail, SCF }\end{array}$ & $\mathrm{H} 1$ & H5 & Yes \\
\hline Mari252 & MNHN252 & L. marinus & mAint & Iles Sainte-Marie, Quebec, Canada & $\begin{array}{l}\text { Gilles Chapdelaine, Jean-François } \\
\text { Rail, SCF }\end{array}$ & $\mathrm{H} 1$ & $\mathrm{H} 5$ & Yes \\
\hline Mari254 & MNHN254 & L. marinus & mAint & Iles Sainte-Marie, Quebec, Canada & $\begin{array}{l}\text { Gilles Chapdelaine, Jean-François } \\
\text { Rail, SCF }\end{array}$ & $\mathrm{H} 1$ & H5 & Yes \\
\hline Mari256 & MNHN256 & L. marinus & mAint & Iles Sainte-Marie, Quebec, Canada & $\begin{array}{l}\text { Gilles Chapdelaine, Jean-François } \\
\text { Rail, SCF }\end{array}$ & $\mathrm{H} 1$ & H5 & Yes \\
\hline Mari257 & MNHN257 & L. marinus & mAint & Iles Sainte-Marie, Quebec, Canada & $\begin{array}{l}\text { Gilles Chapdelaine, Jean-François } \\
\text { Rail, SCF }\end{array}$ & $\mathrm{H} 1$ & $\mathrm{H} 5$ & Yes \\
\hline Mari258 & MNHN258 & L. marinus & mAint & Iles Sainte-Marie, Quebec, Canada & $\begin{array}{l}\text { Gilles Chapdelaine, Jean-François } \\
\text { Rail, SCF }\end{array}$ & $\mathrm{H} 1$ & H5 & Yes \\
\hline Mari260 & MNHN260 & L. marinus & mAint & Iles Sainte-Marie, Quebec, Canada & $\begin{array}{l}\text { Gilles Chapdelaine, Jean-François } \\
\text { Rail, SCF }\end{array}$ & $\mathrm{H} 1$ & H5 & Yes \\
\hline Mari253 & MNHN253 & L. marinus & mAint & Iles Sainte-Marie, Quebec, Canada & $\begin{array}{l}\text { Gilles Chapdelaine, Jean-François } \\
\text { Rail, SCF }\end{array}$ & $\mathrm{H} 18$ & H5 & Yes \\
\hline Mari259 & MNHN259 & L. marinus & mAint & Iles Sainte-Marie, Quebec, Canada & $\begin{array}{l}\text { Gilles Chapdelaine, Jean-François } \\
\text { Rail, SCF }\end{array}$ & $\mathrm{H} 18$ & H5 & Yes \\
\hline Mari16341 & 16341 & L. marinus & mAint & Maine, USA & LSUMZ & $\mathrm{H} 1$ & $x$ & Yes \\
\hline Mari2723 & KU 2723 & L. marinus & mAint & Massachusetts, USA & Mark Robbins, KNHM & $\mathrm{H} 18$ & $x$ & Yes \\
\hline Mari2724 & KU 2724 & L. marinus & mAint & Massachusetts, USA & Mark Robbins, KNHM & $\mathrm{H} 4$ & $x$ & $x$ \\
\hline Mari502 & MNHN502 & L. marinus & mAint & Smithville, Missouri, USA & Mark Robbins, KNHM & $\mathrm{H} 18$ & $\mathrm{H} 5$ & $x$ \\
\hline Mari29 & USNM638662 & L. marinus & mAint & Maryland, USA & NMNH & $\mathrm{H} 1$ & $x$ & Yes \\
\hline Mari15 & USNM638660 & L. marinus & mAint & Maryland, USA & $\mathrm{NMNH}$ & $\mathrm{H} 18$ & $x$ & Yes \\
\hline Mari22 & USNM638692 & L. marinus & mAint & Maryland, USA & NMNH & $\mathrm{H} 18$ & $x$ & Yes \\
\hline Mari03 & USNM84115 & L. marinus & mAint & JFK Airport, New York, USA & NMNH & $\mathrm{H} 1$ & $x$ & Yes \\
\hline Mari06 & USNM641192 & L. marinus & mAint & JFK Airport, New York, USA & $\mathrm{NMNH}$ & $\mathrm{H} 18$ & $x$ & Yes \\
\hline Mari04 & USNM641183 & L. marinus & mAint & JFK Airport, New York, USA & NMNH & $\mathrm{H} 2$ & $x$ & Yes \\
\hline Mari172 & MNHN172 & L. marinus & $\mathrm{mE}$ & Brittany, France & Bernard Cadiou, SEPNB & $\mathrm{H} 2 \mathrm{O}$ & $\mathrm{H} 1$ & Yes \\
\hline Mari174 & MNHN174 & L. marinus & $m E$ & Brittany, France & Bernard Cadiou, SEPNB & $\mathrm{H} 20$ & $\mathrm{H} 1$ & Yes \\
\hline Mari173 & MNHN173 & L. marinus & $m E$ & Brittany, France & Bernard Cadiou, SEPNB & $x$ & $x$ & Yes \\
\hline Mari153 & $\begin{array}{l}\text { AJ276949 } \\
\quad(n=3)\end{array}$ & L. marinus & $m E$ & Faeroe Islands, Denmark & GenBank cf Liebers et al., 2004 & $\mathrm{H} 19$ & $\mathrm{H} 1$ & $x$ \\
\hline Mari155 & AJ508306 & L. marinus & $m E$ & Faeroe Islands, Denmark & GenBank cf Liebers et al., 2004 & $\mathrm{H} 24$ & $\mathrm{H} 1$ & $x$ \\
\hline Mari152 & AJ508305 & L. marinus & $m E$ & Faeroe Islands, Denmark & GenBank cf Liebers et al., 2004 & $\mathrm{H} 25$ & $\mathrm{H} 1$ & $x$ \\
\hline Mari150 & AJ508304 & L. marinus & $m E$ & Faeroe Islands, Denmark & GenBank cf Liebers et al., 2004 & $\mathrm{H} 26$ & $\mathrm{H} 1$ & $x$ \\
\hline Mari149 & $\begin{array}{l}\text { AJ276948 } \\
\quad(n=3)\end{array}$ & L. marinus & $m E$ & Faeroe Islands, Denmark & GenBank cf Liebers et al., 2004 & $\mathrm{H} 27$ & $\mathrm{H} 1$ & $x$ \\
\hline Mari381 & MNHN381 & L. marinus & $m E$ & Ouessant, Brittany, France & Pierre-André Crochet & $\mathrm{H} 20$ & $\mathrm{H} 1$ & Yes \\
\hline Mari384 & MNHN384 & L. marinus & $m E$ & Denmark & Pierre-André Crochet & $\mathrm{H} 30$ & $\mathrm{H} 1$ & Yes \\
\hline Mari199 & MNHN199 & L. marinus & $m E$ & Finland & Visa Rauste, Annika Forsten & $\mathrm{H} 2 \mathrm{O}$ & $\mathrm{H} 1$ & Yes \\
\hline Mari200 & MNHN200 & L. marinus & $m E$ & Finland & Visa Rauste, Annika Forsten & $\mathrm{H} 2 \mathrm{O}$ & $\mathrm{H} 1$ & $x$ \\
\hline Mari195 & MNHN195 & L. marinus & $m E$ & Finland & Visa Rauste, Annika Forsten & $\mathrm{H} 28$ & $\mathrm{H} 1$ & $x$ \\
\hline Mari196 & MNHN196 & L. marinus & $m E$ & Finland & Visa Rauste, Annika Forsten & H31 & $\mathrm{H} 1$ & Yes \\
\hline Mari198 & MNHN198 & L. marinus & $m E$ & Finland & Visa Rauste, Annika Forsten & H31 & $\mathrm{H} 1$ & Yes \\
\hline Mari197 & MNHN197 & L. marinus & $m E$ & Finland & Visa Rauste, Annika Forsten & H32 & $\mathrm{H} 1$ & Yes \\
\hline Mari385 & MNHN385 & L. marinus & $m E$ & Lommer, Sweden & Pierre-André Crochet & H19 & $\mathrm{H} 1$ & Yes \\
\hline Mari383 & MNHN383 & L. marinus & $m E$ & Spillebeng, Malmi, Sweden & Pierre-André Crochet & $\mathrm{H} 2 \mathrm{O}$ & $\mathrm{H} 1$ & Yes \\
\hline Mari382 & MNHN382 & L. marinus & $m E$ & Spillebeng, Sweden & Pierre-André Crochet & $\mathrm{H} 19$ & $\mathrm{H} 1$ & Yes \\
\hline Mari386 & MNHN386 & L. marinus & $m E$ & Spillebeng, Sweden & Pierre-André Crochet & $\mathrm{H} 19$ & $\mathrm{H} 1$ & Yes \\
\hline Mari194 & MNHN194 & L. marinus & $m E$ & Sweden & Pierre-André Crochet & $\mathrm{H} 17$ & $\mathrm{H} 3$ & $x$ \\
\hline smi497 & DOT10247 & L. smithsonianus & $s$ & New York, USA & AMNH & $\mathrm{H} 1$ & $\mathrm{H} 5$ & Yes \\
\hline Smi501 & PRS 205 & L. smithsonianus & $s$ & North Branch, New Jersey, USA & AMNH & $\mathrm{H} 1$ & H5 & Yes \\
\hline Smi10245 & DOT10245 & L. smithsonianus & $s$ & JFK Airport, New York, USA & AMNH & $\mathrm{H} 1$ & $x$ & Yes \\
\hline Smi10247 & DOT10247 & L. smithsonianus & $s$ & JFK Airport, New York, USA & AMNH & $\mathrm{H} 1$ & $x$ & Yes \\
\hline Smi10248 & DOT10248 & L. smithsonianus & $s$ & JFK Airport, New York, USA & AMNH & $\mathrm{H} 1$ & $x$ & Yes \\
\hline Smi10250 & DOT10250 & L. smithsonianus & $s$ & JFK Airport, New York, USA & AMNH & $\mathrm{H} 1$ & $x$ & Yes \\
\hline
\end{tabular}


Appendix 1 (Continued)

\begin{tabular}{|c|c|c|c|c|c|c|c|c|}
\hline $\begin{array}{l}\text { Specimen } \\
\text { number }\end{array}$ & Tissue number & Species & Group & Localities & Collector, Institution & HVR-I & Cyt $b$ & Microsatellites \\
\hline Smi10252 & DOT10252 & L. smithsonianus & $s$ & JFK Airport, New York, USA & AMNH & $\mathrm{H} 1$ & $x$ & Yes \\
\hline Smi498 & PRS 1618 & L. smithsonianus & $s$ & JFK Airport, New York, USA & AMNH & $\mathrm{H} 1$ & $x$ & Yes \\
\hline Smi7269 & DCP 100 & L. smithsonianus & $s$ & Jake's Landing, New Jersey, USA & ANSP & $\mathrm{H} 2$ & $x$ & Yes \\
\hline Smi 1 & $\begin{array}{l}\text { AJ277127 } \\
\quad(n=7)\end{array}$ & L. smithsonianus & $s$ & Lake Huron, Ontario, Canada & GenBank cf (Liebers et al., 2004) & $\mathrm{H} 1$ & H5 & $x$ \\
\hline Smi2 & AJ276946 & L. smithsonianus & $s$ & Lake Huron, Ontario, Canada & GenBank cf (Liebers et al., 2004) & $\mathrm{H} 11$ & $x$ & $x$ \\
\hline Smi3 & $\begin{array}{l}\text { AJ276938 } \\
\quad(n=3)\end{array}$ & L. smithsonianus & $s$ & Lake Huron, Ontario, Canada & GenBank cf (Liebers et al., 2004) & $\mathrm{H} 2$ & $\mathrm{H} 4$ & $x$ \\
\hline Smi505 & 24405 & L. smithsonianus & $s$ & Riverside Co, California, USA & Donna Dittmann, LSUMZ & $x$ & $x$ & Yes \\
\hline Smi437 & 5885 & L. smithsonianus & $s$ & California & Donna Dittmann, LSUMZ & $\mathrm{H} 1$ & $\mathrm{H} 5$ & Yes \\
\hline Smi436 & 26270 & L. smithsonianus & $s$ & Louisiana, USA & Donna Dittmann, LSUMZ & $\mathrm{H} 1$ & H5 & Yes \\
\hline Smi440 & 22548 & L. smithsonianus & $s$ & Louisiana, USA & Donna Dittmann, LSUMZ & $\mathrm{H} 1$ & $\mathrm{H} 5$ & Yes \\
\hline Smi441 & 32863 & L. smithsonianus & $s$ & Louisiana, USA & Donna Dittmann, LSUMZ & $\mathrm{H} 1$ & H5 & Yes \\
\hline Smi443 & 1438 & L. smithsonianus & $s$ & Louisiana, USA & Donna Dittmann, LSUMZ & $\mathrm{H} 1$ & H5 & Yes \\
\hline Smi445 & 1439 & L. smithsonianus & $s$ & Louisiana, USA & Donna Dittmann, LSUMZ & $\mathrm{H} 1$ & H5 & Yes \\
\hline Smi446 & 1598 & L. smithsonianus & $s$ & Louisiana, USA & Donna Dittmann, LSUMZ & $\mathrm{H} 11$ & H5 & Yes \\
\hline Smi439 & 1597 & L. smithsonianus & $s$ & Louisiana, USA & Donna Dittmann, LSUMZ & H5 & $\mathrm{H} 5$ & Yes \\
\hline Smi504 & 24404 & L. smithsonianus & $s$ & Riverside Co, California, USA & Donna Dittmann, LSUMZ & $x$ & $x$ & Yes \\
\hline Smi261 & MNHN261 & L. smithsonianus & $s$ & Iles Sainte-Marie, Quebec, Canada & $\begin{array}{l}\text { Gilles Chapdelaine, Jean-François } \\
\text { Rail, SCF }\end{array}$ & $\mathrm{H} 1$ & $\mathrm{H} 5$ & $x$ \\
\hline Smi262 & MNHN262 & L. smithsonianus & $s$ & Iles Sainte-Marie, Quebec, Canada & $\begin{array}{l}\text { Gilles Chapdelaine, Jean-François } \\
\text { Rail, SCF }\end{array}$ & $\mathrm{H} 1$ & $\mathrm{H} 5$ & Yes \\
\hline Smi263 & MNHN263 & L. smithsonianus & $s$ & Iles Sainte-Marie, Quebec, Canada & $\begin{array}{l}\text { Gilles Chapdelaine, Jean-François } \\
\text { Rail, SCF }\end{array}$ & $\mathrm{H} 1$ & H5 & Yes \\
\hline Smi270 & MNHN270 & L. smithsonianus & $s$ & Iles Sainte-Marie, Quebec, Canada & $\begin{array}{l}\text { Gilles Chapdelaine, Jean-François } \\
\text { Rail, SCF }\end{array}$ & $\mathrm{H} 1$ & $\mathrm{H} 5$ & Yes \\
\hline Smi271 & MNHN271 & L. smithsonianus & $s$ & Iles Sainte-Marie, Quebec, Canada & $\begin{array}{l}\text { Gilles Chapdelaine, Jean-François } \\
\text { Rail, SCF }\end{array}$ & $\mathrm{H} 1$ & H5 & $x$ \\
\hline Smi272 & MNHN272 & L. smithsonianus & $s$ & Iles Sainte-Marie, Quebec, Canada & $\begin{array}{l}\text { Gilles Chapdelaine, Jean-François } \\
\text { Rail, SCF }\end{array}$ & $\mathrm{H} 1$ & $\mathrm{H} 5$ & Yes \\
\hline Smi275 & MNHN275 & L. smithsonianus & $s$ & Iles Sainte-Marie, Quebec, Canada & $\begin{array}{l}\text { Gilles Chapdelaine, Jean-François } \\
\text { Rail, SCF }\end{array}$ & $\mathrm{H} 1$ & $\mathrm{H} 5$ & Yes \\
\hline Smi276 & MNHN276 & L. smithsonianus & $s$ & Iles Sainte-Marie, Quebec, Canada & $\begin{array}{l}\text { Gilles Chapdelaine, Jean-François } \\
\text { Rail, SCF }\end{array}$ & $\mathrm{H} 1$ & $\mathrm{H} 5$ & Yes \\
\hline Smi264 & MNHN264 & L. smithsonianus & $s$ & Iles Sainte-Marie, Quebec, Canada & $\begin{array}{l}\text { Gilles Chapdelaine, Jean-François } \\
\text { Rail, SCF }\end{array}$ & $\mathrm{H} 1$ & $\mathrm{H} 5$ & Yes \\
\hline Smi266 & MNHN266 & L. smithsonianus & $s$ & Iles Sainte-Marie, Quebec, Canada & $\begin{array}{l}\text { Gilles Chapdelaine, Jean-François } \\
\text { Rail, SCF }\end{array}$ & $\mathrm{H} 12$ & $\mathrm{H} 5$ & Yes \\
\hline Smi279 & MNHN279 & L. smithsonianus & $s$ & Iles Sainte-Marie, Quebec, Canada & $\begin{array}{l}\text { Gilles Chapdelaine, Jean-François } \\
\text { Rail, SCF }\end{array}$ & $\mathrm{H} 12$ & $\mathrm{H} 5$ & Yes \\
\hline Smi280 & MNHN280 & L. smithsonianus & $s$ & Iles Sainte-Marie, Quebec, Canada & $\begin{array}{l}\text { Gilles Chapdelaine, Jean-François } \\
\text { Rail, SCF }\end{array}$ & $\mathrm{H} 12$ & $\mathrm{H} 5$ & Yes \\
\hline Smi268 & MNHN268 & L. smithsonianus & $s$ & Iles Sainte-Marie, Quebec, Canada & $\begin{array}{l}\text { Gilles Chapdelaine, Jean-François } \\
\text { Rail, SCF }\end{array}$ & $\mathrm{H} 13$ & $\mathrm{H} 5$ & Yes \\
\hline Smi274 & MNHN274 & L. smithsonianus & $s$ & Iles Sainte-Marie, Quebec, Canada & $\begin{array}{l}\text { Gilles Chapdelaine, Jean-François } \\
\text { Rail, SCF }\end{array}$ & $\mathrm{H} 14$ & $\mathrm{H} 5$ & Yes \\
\hline Smi267 & MNHN267 & L. smithsonianus & $s$ & Iles Sainte-Marie, Quebec, Canada & $\begin{array}{l}\text { Gilles Chapdelaine, Jean-François } \\
\text { Rail, SCF }\end{array}$ & $\mathrm{H} 2$ & $\mathrm{H} 5$ & Yes \\
\hline Smi273 & MNHN273 & L. smithsonianus & $s$ & Iles Sainte-Marie, Quebec, Canada & $\begin{array}{l}\text { Gilles Chapdelaine, Jean-François } \\
\text { Rail, SCF }\end{array}$ & $\mathrm{H} 2$ & $\mathrm{H} 5$ & Yes \\
\hline Smi277 & MNHN277 & L. smithsonianus & $s$ & Iles Sainte-Marie, Quebec, Canada & $\begin{array}{l}\text { Gilles Chapdelaine, Jean-François } \\
\text { Rail, SCF }\end{array}$ & $\mathrm{H} 2$ & $\mathrm{H} 5$ & Yes \\
\hline Smi269 & MNHN269 & L. smithsonianus & $s$ & Iles Sainte-Marie, Quebec, Canada & $\begin{array}{l}\text { Gilles Chapdelaine, Jean-François } \\
\text { Rail, SCF }\end{array}$ & $\mathrm{H} 8$ & $\mathrm{H} 5$ & Yes \\
\hline Smi265 & MNHN265 & L. smithsonianus & $s$ & Iles Sainte-Marie, Quebec, Canada & $\begin{array}{l}\text { Gilles Chapdelaine, Jean-François } \\
\text { Rail, SCF }\end{array}$ & $\mathrm{H} 9$ & H5 & Yes \\
\hline Smi278 & MNHN278 & L. smithsonianus & $s$ & Iles Sainte-Marie, Quebec, Canada & $\begin{array}{l}\text { Gilles Chapdelaine, Jean-François } \\
\text { Rail, SCF }\end{array}$ & $\mathrm{H} 9$ & $\mathrm{H} 5$ & Yes \\
\hline
\end{tabular}


Appendix 1 (Continued)

\begin{tabular}{|c|c|c|c|c|c|c|c|c|}
\hline $\begin{array}{l}\text { Specimen } \\
\text { number }\end{array}$ & Tissue number & Species & Group & Localities & Collector, Institution & HVR-I & Cyt b & Microsatellites \\
\hline Smi16 & USNM638657 & L. smithsonianus & $s$ & Maryland, USA & NMHN & $\mathrm{H} 1$ & $x$ & Yes \\
\hline Smi17 & USNM638658 & L. smithsonianus & $s$ & Maryland, USA & NMHN & $\mathrm{H} 12$ & $x$ & Yes \\
\hline Sm24 & USNM638685 & L. smithsonianus & $s$ & Maryland, USA & NMHN & $\mathrm{H} 15$ & $x$ & Yes \\
\hline Smi18 & USNM638659 & L. smithsonianus & $s$ & Maryland, USA & NMHN & $\mathrm{H} 16$ & $x$ & Yes \\
\hline Smi11 & USNM641186 & L. smithsonianus & $s$ & JFK Airport, New York, USA & NMHN & $\mathrm{H} 1$ & $x$ & Yes \\
\hline Smi26 & USNM638687 & L. smithsonianus & $s$ & Maryland, USA & NMHN & $x$ & $x$ & Yes \\
\hline Smi19 & USNM638688 & L. smithsonianus & $s$ & Maryland, USA & NMHN & $x$ & $x$ & Yes \\
\hline Smi447 & $\begin{array}{c}\text { UAMX2122, } \\
1598\end{array}$ & L.smithsonianus & $s$ & Alaska, USA & University of Alaska Museum & $x$ & $x$ & Yes \\
\hline Smi448 & UAMX2123 & L.smithsonianus & $s$ & Alaska, USA & University of Alaska Museum & $x$ & $x$ & Yes \\
\hline Smi449 & UAMX2124 & L.smithsonianus & $s$ & Alaska, USA & University of Alaska Museum & $x$ & $x$ & Yes \\
\hline Smi450 & UAMX2126 & L.smithsonianus & $s$ & Alaska, USA & University of Alaska Museum & $x$ & $x$ & Yes \\
\hline Smi451 & UAMX2128 & L.smithsonianus & $s$ & Alaska, USA & University of Alaska Museum & $x$ & $x$ & Yes \\
\hline
\end{tabular}

Abbreviations: AMNH, American Museum of Natural History; ANSP, Academy of Natural Sciences of Philadelphia; KNHM, Kansas Natural History Museum; LSUMZ, Louisiana State University Museum of Zoology; NMNH, National Museum of Natural History, Smithsonian Institution; SCF, Service Canadien de la Faune; SEPNB, Société d'Etudes et de Protection de la Nature en Bretagne. 